\title{
The Political Consequences of Household Wealth Shocks: Evidence from Italy
}

\author{
Giovanni Angioni ${ }^{\dagger}$, Jeffrey Chwieroth ${ }^{\dagger}$, Jonathan Hopkin ${ }^{\dagger}$, and \\ Andrew Walter $\ddagger$ \\ ${ }^{\dagger}$ London School of Economics and Political Science \\ $\ddagger$ University of Melbourne
}

September 2020

\begin{abstract}
How do adverse shocks to household wealth influence domestic politics? Household wealth has become increasingly salient because rising financialization and trends in the cost and provision of crucial services have increased risks to many households. Wealth shocks can undermine support for mainstream political parties that have converged on policies perceived as contributing to the shock, compounding rising anxiety in the squeezed middle class and increasing the attractiveness of anti-system voting.

This paper makes use of fine-grained time series data on household income and wealth in Italy to identify voters with greater exposure to these shocks, assessing how developments in the levels and distribution of household wealth, leverage, and financial vulnerability have shaped voter dissatisfaction with mainstream politics and promoted voting for populist parties since 1992.

Results suggest that financial distress is indeed connected to populist voting. Wealthier parts of the electorate are more invested in the status quo, supporting parties that have demonstrated their commitment to fiscal and monetary orthodoxy. Nonetheless, some exposure to financial risk, such as share ownership or high levels of leverage, seem to push voters towards populist parties.
\end{abstract}

Preliminary version for APSA 2020. Please do not cite or quote without the authors' permission. 


\section{Introduction}

The literature on populism has offered a wide range of potential explanations of the recent marked rise of political populism, including trade shocks, skill-biased technological change, economic crises and associated fiscal austerity, immigration, as well as identity divides and culture wars that may be exacerbated by new social media. One important cross-cutting theme has been the way in which these factors generate or exacerbate spatial asymmetries and group identity divides, which in turn shape perceptions of positional or relative deprivation. The literature has been dominated by the "economics vs culture" debate and by competing assessments of the relative impact of fiscal austerity, unemployment, immigration, rising income inequality, and the erosion of manufacturing employment and wages in the political economy literature. Financial factors have so far played more of an indirect role in most of this literature, notably through the macroeconomic and distributional impact of the global financial crises that began in 2007.

This paper investigates the more direct potential role of financial factors in populist voting. It does so by analyzing an important national case, Italy, where populist parties were able to form a government in 2018 and have won the support of over half the electorate in recent years. We assess how developments in the levels and distribution of household wealth, leverage, and financial vulnerability have shaped voter dissatisfaction with mainstream politics and promoted voting for populist parties in Italy since 1992. Like many other countries, Italy has been subject to many of the forces identified in the populism literature, including trade shocks and manufacturing decline, sustained poor macroeconomic outcomes, growing financial market exposure in the household sector, and rising government and corporate indebtedness (GarciaMacia 2018). Italy also exhibits large, persistent regional asymmetries and tensions, pointing to the important role of spatial factors and regional divides in Italian politics. Importantly for our analysis, Italy has also experienced significant financial developments in recent years: a systemic banking crisis beginning in 2008, an extended period of banking fragility culminating in a series of bank bailouts in 2017, and sharply declining median net household wealth after 2010, primarily driven by continuously declining real house prices since 2007 (Banca d'Italia 2018; Bank for International Settlements 2019; Laeven and Valencia 2018; Merler 2016; Merler 2017). We exploit the availability of regional-level data to assess the direct role of financial factors in this crucial case.

Populism remains a contested concept, although most authors identify how populists typically assert the legitimacy of "the people", as distinct from corrupt elites (Mudde and Cristobal 2017). Many focus on recent far right nationalist and nativist variants of populism (Carreras, Irepoglu Carreras, and Bowler 2019; Eichengreen 2018; Müller 2019; Norris and Inglehart 2019), while others explore the rise of nonmainstream "radical" right and left parties that may be "anti-liberal" (Burgoon et al. 2019; Matthijs Rooduijn and Akkerman 2017). Others include "anti-system" political entrepreneurs and parties such as secessionists as well as insurgents who build new po- 
litical movements and parties or attempt to capture mainstream parties (Hopkin 2020). In what follows, we adopt a broad definition of populism that includes any candidate or party that seeks to mobilize political support based on a rhetorical dualism between the "people" and "elites" or other out-groups.

\section{Theory}

Much has been written about whether economic or cultural factors are the more important causes of populism and how easily they can be distinguished (Morgan 2018; Mutz 2018; Norris and Inglehart 2019). Cultural theories emphasize the role of values and identity politics in the populist backlash of recent years (Inglehart 1997; Inglehart and Norris 2016; Norris and Inglehart 2019). They reject arguments that relatively recent economic developments can explain this cultural backlash, arguing that it has longer term, structural causes that persist over the economic cycle - though they do allow a role for economic shocks in activating latent cultural values. Difficulties with cultural accounts include the problem that culture evolves slowly whereas populism has risen sharply in recent years, that "economic" explanations are neither necessarily incompatible with them nor only focused on short term cyclical shocks.

In practice, distinguishing the causal impact of values conflicts is very challenging (Gennaioli and Tabellini 2019; Morgan 2018; Rodrik 2020). Most obviously, economic shocks can trigger and sharpen individuals' cultural frames (Carreras, Irepoglu Carreras, and Bowler 2019; Hopkin 2020), and long term trends in relative economic fortunes can shape perceptions of social status (Burgoon et al. 2019; Gidron and Hall 2017; Rodríguez-Pose 2018). Large income and employment shocks can also undermine voter trust in political institutions, including the mainstream political parties long associated with them (Algan et al. 2017). On the political "supply" side, there are many historical and contemporary examples of opportunistic populists targeting voters experiencing relative economic deprivation with nativist and tribal messaging by blaming mainstream elites for betraying the interests of the people and by targeting out-groups who supposedly benefit unfairly (Berman 2006, pp. 140-142; Ford and Goodwin 2014).

"Demand"-side variables include the usual factors identified in the economic voting literature, notably trends in aggregate employment and real income, as well as their distribution, and cuts in welfare benefits. These underlying variables thought to drive political behaviour remain at the core of many political economy investigations of the impact of trade, technological change, economic crises, fiscal austerity and immigration on populist voting.

Most of this literature has focused on the role of income effects on voter senti-

ment. Some analyses focus on classic forces associated with economic globalization, notably trade and foreign direct investment (FDI) with their fairly well-understood distributional consequences, arguing that by generating relative employment and income 
deprivation for some groups they encourage a backlash against mainstream political parties (Autor, Dorn, and G. H. Hanson 2016; Autor, Dorn, G. Hanson, et al. 2016; Colantone and Stanig 2018a; Milner 2019). Technological change, demographic change, and labour market, welfare and tax policies, including the fiscal austerity that often follows deep recessions, can also compound these distributional effects and reinforce perceptions of status decline among disadvantaged groups (Dal Bo et al. 2019; Fetzer 2019; Vlandas and Halikiopoulou 2018). Globalization and associated skill-biased technological change in particular may generate growing status gaps between educated, mobile economic elites and less mobile workers facing much greater economic and social risk (Collier 2018).

There is less agreement on which forms of political populism these factors will favour. Rodrik argues that the perceived source of income shock may be important in this regard, claiming that far right populism is the more likely beneficiary when immigration and refugee flows are important contributors to income shocks (because they foster identity conflicts), whereas trade, finance, and FDI will tend to divide along class lines and favour left wing populism (Rodrik 2018). Others disagree, arguing that the China trade shock favours right wing populism because it creates stark divides between economic winners and losers who are often concentrated in specific localities and increasingly culturally distinct (Autor, Dorn, and G. H. Hanson 2016; Cerrato, Ferrara, and Ruggieri 2018; Steiner and Harms 2020). Burgoon et al. (Burgoon et al. 2019) argue that groups experiencing extended periods of positional deprivation relative to knowledge workers and the very wealthy are more likely to vote for radical left parties, whereas those experiencing perceived positional deprivation relative to the poor or historically disadvantaged are more likely to vote for the radical right. What is less clear is what happens if both forms of positional deprivation occur simultaneously, which seems to be true for white working class males in a number of advanced countries.

Various authors have argued convincingly that the spatial aspects of relative deprivation are politically important (Enos 2017; Wilkinson 2019), including by fostering resentment in deprived communities of outsiders they perceive as privileged or out-groups seen as threats to their wellbeing (Autor, Dorn, G. Hanson, et al. 2016; Rodríguez-Pose 2018). Ansell and Cansunar argue that less secure households and individuals have a more accurate grasp of local economic conditions than the relatively privileged who are often more marginally attached to their local communities, which could amplify the likelihood that the former will defect to political alternatives when experiencing long term relative deprivation (Ansell and Cansunar 2020). Since declining communities often find it difficult to sustain the provision of local public goods, this can exacerbate the perception of long term residents that they must compete more intensely for resources with members of out-groups (Autor, Dorn, G. Hanson, et al. 2016, p. 4).

The political supply side may be crucial in this regard. As Dal Bó et al. (Dal Bo et al. 2019) show in the case of Sweden, the ability of far right populist parties to front candidates in elections who are perceived as authentic and representative by groups 
experiencing relative deprivation has been a decisive advantage compared to left and centre left parties' tendency to supply more educated candidates. The far right's often brazen willingness to use language that elites see as unacceptable, including the identification and targeting of out-groups, seem to have allowed them to pull votes of the disaffected away from more restrained politicians. At least in some prominent cases, the far right may also have been more adept at using new social media as tools of political mobilization. Finally, to the extent that globalization, technological change and other factors have promoted increasing group cleavages within countries, this may have eroded the national collective solidarity that underpinned postwar social welfare states in many advanced countries, eroding the appeal of left and centre-left policy solutions to longstanding problems of deprivation and of compensating economic losers (Colantone and Stanig 2018b; Steiner and Harms 2020).

There is a smaller literature on financial and wealth factors in the rise of populism. Literature on "patrimonial voting", which is closely connected to the traditional economic voting literature, suggests that contemporary wealth inequality may now have a greater impact on voting behaviour than income inequality (Lewis-Beck, Nadeau, and Foucault 2013; Persson and Martinsson 2018; Piketty 2019). Since rising economic inequality generally is often seen as an important cause of perceived relative deprivation, rising wealth inequality is a plausible contributor to the sense of political alienation felt by the "left behind", and by eroding collective solidarity may be more likely to favour far right populism.

Other work has taken a longer historical perspective. Funke, Schularick and Trebesch (Funke, Schularick, and Trebesch 2016) find that financial crises are associated with increased vote shares for far right parties, many of which have been seen as populist, over nearly 150 years. Since they also find this effect does not hold in the aftermath of "normal" recessions or severe non-financial economic shocks, this suggests that the financial aspect of crises is distinctive in its impact. The authors suggest that financial crises increase economic and policy uncertainty that may mobilise votes for candidates offering nativist or anti-minority rhetoric and policies (though quite why left wing populists cannot also capitalize on such uncertainty is less clear).

Banking crises more specifically could play an important role in fostering populist voting in particular geographic locations. In a micro-level analysis of Germany in the aftermath of the failure of two major banks in 1931, Doerr and co-authors (Doerr et al. 2019) show that branch failures for a major bank (Danatbank) conspicuously associated with prominent Jewish management sharply increased voting for far right candidates in 1932, especially in local areas with a history of anti-Semitism. What is less clear is the mechanism by which bank branch failures foster far right voting. This may be linked to the possible impact on local businesses and community wellbeing.

Other work focuses on the direct "pocketbook" effects of housing market shocks which can be linked to financial crises - on household wealth (Ahlquist, Copelovitch, and S. Walter 2020; Gyongyosi and Verner 2019). These authors find that voters in Polish and Hungarian households that had previously taken out foreign currency mortgages to purchase houses who suffered significant losses when the Swiss franc appreci- 
ated sharply against the zloty and forint after 2008 and 2015 respectively were drawn to populist parties offering compensation. Importantly, the supply-side also matters: populist policy rhetoric supporting household bailouts at the expense of banks and other taxpayers encouraged hitherto mainstream Hungarian parties to emulate them (Gyongyosi and Verner 2019).

These findings are consistent with other work that has found that negative wealth shocks during and after banking crises have had an increasingly significant negative impact on political support for incumbent governments - the vast majority of whom have been comprised of "mainstream" rather than populist parties - since the early 1970s (Chwieroth and A. Walter 2019; Chwieroth and A. Walter 2020). These authors argue that this trend is strongly associated with the gradual emergence of generalized expectations that governments have a responsibility to protect household wealth. When governments fail to offer effective protection, this generates growing dissatisfaction with mainstream policies and associated political elites. As Gyöngyösi and Verner and Ahlquist et al. also suggest, expectations of government protection are likely to be strongest in the presence of rising household leverage, which amplifies the size of pocketbook wealth shocks. Leveraged homeowners have strong incentives to focus on the market value of their house or apartment if they perceive market risk, and experience larger real losses when prices fall.

If the pocketbook effects of wealth shocks are potentially important in generating voter dissatisfaction with establishment political elites, it is not clear why housing wealth alone should matter. Pension wealth in particular is also an important component of household wealth in many countries and if it takes the form of financial assets in defined contribution schemes, this can produce large household wealth shocks during crises. Anxiety over such wealth shocks can be exacerbated by fiscal austerity, as cuts to and reforms of public welfare provision, especially when accompanied by steadily rising costs of key services such as education and healthcare, can further squeeze households dependent upon their supply whose personal liquid wealth is low or at risk (Ansell 2014; Frank 2013; OECD 2019).

Mass societal wealth - in both property and pensions - has at the same time become increasingly "financialized" and thereby exposed to rising risk (Chwieroth and A. Walter 2019). This may contribute to rising anxiety, a growing perception of relative deprivation, and resentment of the mainstream political elites that have promoted and supported such policy reforms, often over successive governments of the centre-right and centre-left (Berman and Snegovaya 2019; Evans and Tilley 2017; Guiso et al. 2017; Massey 2013; Milner 2018; Mudge 2018).

Italy is a notable example in this sense. Right-wing governments led by the populist Silvio Berlusconi between 1994 and 2013 promoted financial deregulation and entrepreneur-friendly tax cuts (Taguieff 2003). Centre-left coalitions, such as the Ulivo, which alternated in government with the Right during the same period, failed to promote effective welfare reforms favouring the weakest strata, instead favouring labour market deregulation and tax rises to meet European budgetary requirements, often in response to the Berlusconi governments' lax fiscal approach. As a consequence, 
they antagonized voters even more, while economic growth stagnated and inequality increased even before the Global Financial Crisis. Afterwards, Berlusconi's Forza Italia was forced to adopt austerity measures, and ultimately hand over power to technocrats supported by the centre-left parties to impose a new round of emergency fiscal tightening.

As a result the mainstream party system were easily characterized as an éliteoriented cartel by the new populist party, the Five Star Movement, that emerged as the biggest party in the 2013 election (D'Alimonte 2019). A completely new party with unclear ideological moorings, founded by a comedian, Beppe Grillo, the Five Star Movement focused mainly on condemning the corruption of the established political parties, but did also campaign against the Euro, labour market reforms, and corporate malfeasance. With Five Stars unwilling to work in coalition with any of the established parties, the centre-left Democratic Party governed, again with support from elements of the Right, between 2013 and 2018, with an even more marked orientation towards economic liberalism and job market deregulation. The European Union institutions were seen as the source of these unpopular policies and their harsh consequences for living standards, potentially tarring all the mainstream pro-EU political parties with a neoliberal brush in the eyes of disaffected voters. Policies to contain public debt and stabilize the pension system were perceived as particularly disadvantaging Italy's very large number of small entrepreneurs and the self-employed ("partite IVA") - especially in the Centre/South - while being favourable to wealthy Northern industrialists and high income households in the large cities, adding a territorial dimension to the costs of crisis.

In many countries it was the extreme right of the populist ideological spectrum more than the extreme left that led a backlash against these policies (Kriesi 2014, p. 369). Historically, many early incarnations of extreme right populist political movements began as economic conservatives but evolved to embrace social protection policies, a move that accelerated in Europe after the 2007-9 financial crises (Berman and Snegovaya 2019, pp. 9-10). The result was that left parties were often no longer trusted by many voters who the party leaderships believed were their "natural" constituency. Italy was ripe for this kind of response because the traditional party of the left, the Democratic Party, had evolved from its roots in the Communist International to become a centrist, liberal and pro-European party, more concerned with fiscal probity than redistribution. This evolution left a gap in the political space opposing austerity and the anti-inflationary bias of European Monetary Union. In the Italian case this gap was largely filled initially by the Five Star Movement, but after 2017 the populist Northern League, historically a right-wing regionalist party advocating the secession of Northern Italy, adopted a typical right-populist anti-migration and Euroskeptic platform under its new leader Matteo Salvini, extending its support beyond the North.

Reprising the spatial dimensions of populism, Adler and Ansell (Adler and Ansell 2019; Ansell and Adler 2019) argue that it draws its strength at least in part from a "geography of discontent" that arises when particular communities experience relative decline and deprivation that are manifested in and symbolized by declining relative 
house prices. They describe this as a "geotropic" effect as distinct from the pocketbook impact on individual wealth. They provide evidence that local areas in Britain and France in which house prices have relatively underperformed or fallen over the long term are associated with a politics of growing resentment that favours populist voting. Falling relative house prices in such areas can also attract low-income immigrants, which can contribute to locals' perceptions that they are under siege (Enos 2017, Chapter 8). Thus, households and voters in such disadvantaged communities may be attracted to populist parties that identify and target minorities, immigrants, external elites and specific policies seen as locally disadvantageous. The unevenness of house price trends - often rising dramatically in major cities increasingly dominated by cosmopolitan knowledge workers, while stagnating or falling in economically declining areas - sharpens perceived societal divides in ways that cut across traditional mainstream party lines and favour far right forms of populism. The very large differences in income and wealth in Italy between North and South lead us to expect distinct impacts of financial shocks across regions.

We do not claim that only wealth shocks will matter for voter disaffection with mainstream political parties and defection to populist alternatives. Indeed, the sensitivity of voters to wealth inequality, shocks and longer term financial developments is likely to be higher when voters have also experienced other sources of rising perceived vulnerability, including welfare and labour market reform, globalization and technological change, and wide losses in household income. However we can sketch out some theoretical expectations that can be tested against the Italian data, distinguishing between the longer term trends emerging from the liberalization and Europeanization of the Italian economy since the 1990s, and the shorter-term cyclical effects of the Global Financial Crisis, the Italian sovereign debt crisis, and the harsh austerity which followed.

In terms of longer term trends, the rise in wealth inequality can be expected to reduce social solidarity and increase resentment among those experiencing relative deprivation, benefitting populist challengers. The growth of personal debt among some groups reinforces their perceived relative vulnerability and anxiety, which could lead to increased support for Right-wing populism if it focuses voter attention on grievances with out-groups perceived as beneficiaries of mainstream party largesse, but alternatively, could benefit mainstream, more fiscally orthodox parties if these voters fear that populists' policy proposals threaten asset prices. Local relative house price declines could reinforce perceptions of local community deprivation and declining national solidarity, benefitting far right populism (the "geotropic effect").

In the shorter term, the financial crises raise anxiety about household wealth resources, potentially discrediting mainstream party governments that are perceived to have failed in their duty to protect household assets, favouring an alternative populist offer that can propose a plausibly more effective policy response. Financial shocks can have variegated effects in the presence of local bank failures, where perceptions of regulatory failure or political corruption can lead to mainstream parties losing credibility and opening up opportunities for populist challengers. Financial threats are also fil- 
tered through welfare, pension and labour market reforms that can increase reliance on personal savings for some groups, whilst exposing others to high or rising leverage; either way financial shocks have a direct "pocketbook effect" that discredits mainstream political parties, exacerbates societal divides and has the potential to favour populist or anti-system voting. We are interested in two broad dimensions of the electoral response to financial shocks: first, whether voters support establishment or mainstream political parties, or populist anti-system forces; and second, whether populist voting leans to the Left or to the Right of the established parties.

\section{Data}

We use a novel database on election outcomes in Italy's regions from 1992 to 2018 to test our argument and its empirical implications. We obtain a panel of 20 regions, with all data aggregated at the regional level. Table 1 provides the summary statistics. Our primary interest is to assess how household wealth, leverage, and financial vulnerability shape voting for populist parties. In addition to this, we discuss the role of supplyside factors by considering the evolution of party leader rhetoric and party platforms relating directly to household finances and wealth.

Table 1: Summary statistics after collapsing at regional level

\begin{tabular}{lccccc}
\hline Variable & Obs & Mean & Std. Dev. & Min & Max \\
\hline House value (log) & 629 & 11.90833 & .5059698 & 10.47959 & 12.95458 \\
House debt (log) & 623 & 8.039336 & .9669074 & 2.818982 & 9.886505 \\
Net wages (log) & 629 & 8.630247 & .2208875 & 7.869532 & 9.100317 \\
Share females & 629 & 51.19519 & 1.729954 & 39.62264 & 55.38881 \\
Share unemployed & 628 & 2.892331 & 1.916737 & 0 & 10.80332 \\
Share university education & 629 & 7.851436 & 3.133502 & 2.702703 & 17.47466 \\
Age & 629 & 43.3911 & 4.971862 & 32 & 55 \\
Import shock & 460 & .3954213 & .689853 & -1.119552 & 4.374968 \\
Net wealth (log) & 553 & 12.18819 & .4199646 & 10.90783 & 13.14194 \\
Financial liabilities & 551 & 8095.93 & 4790.103 & 408.5445 & 26139.81 \\
Shares (amount) & 615 & 1224.354 & 1566.852 & 0 & 9607.658 \\
Shares (percentage holding) & 625 & .0521348 & .04563 & 0 & .2347412 \\
Bonds (amount) & 610 & 1639.054 & 2209.545 & 0 & 13525.57 \\
Bonds (percentage holding) & 619 & .052143 & .051281 & 0 & .2903226 \\
Private pensions (log) & 576 & 4.571679 & 1.163764 & -2.13942 & 6.600266 \\
Share holding private pensions & 591 & 5.38043 & 4.464413 & 0 & 22.7451 \\
Share wealth poor & 629 & 36.93566 & 12.08688 & 4.545455 & 72.85547 \\
Share financially vulnerable & 629 & 3.215369 & 1.79769 & 0 & 9.933775 \\
House value change since max & 609 & -.007839 & .1421331 & -.4892282 & .3677187 \\
Net wealth change since max & 533 & -.0678047 & .2016685 & -1.137547 & .4650755 \\
Financial liabilities change since max & 531 & -.1648365 & .3647936 & -.9750903 & 2.793447 \\
House value change since previous election & 624 & -.1289816 & .4403915 & -2.427778 & .6422682 \\
Net wealth change since previous election & 552 & -.0087109 & .2487102 & -1.70042 & 1.081576 \\
Financial liabilities change since previous election & 550 & -.2309419 & 1.609048 & -26.77504 & .8386393 \\
\hline & & & & & 0 \\
\hline
\end{tabular}

We analyze the vote share of populist parties at the regional level in eight rounds 
of national parliamentary elections (1992, 1994, 1996, 2001, 2006, 2008, 2013, 2018). These data are from the Ministry of Domestic Affairs's Historical Electoral Archive. They show clearly the steady rise in populist vote share in Italy since the early 1990s, and its acceleration in the wake of the Global Financial Crisis and subsequent sovereign debt crisis in the Eurozone.

The regional decomposition of populist vote shares illustrate that the industrialized and wealthy North accounted disproportionately for the populist vote share in the $1990 \mathrm{~s}$, but in the more recent period the shares have converged across regions, as the League and Forza Italia have been joined by the Five Star Movement which has had a more uniform distribution across regions with a slight skew in favour of the South.

Figure 1

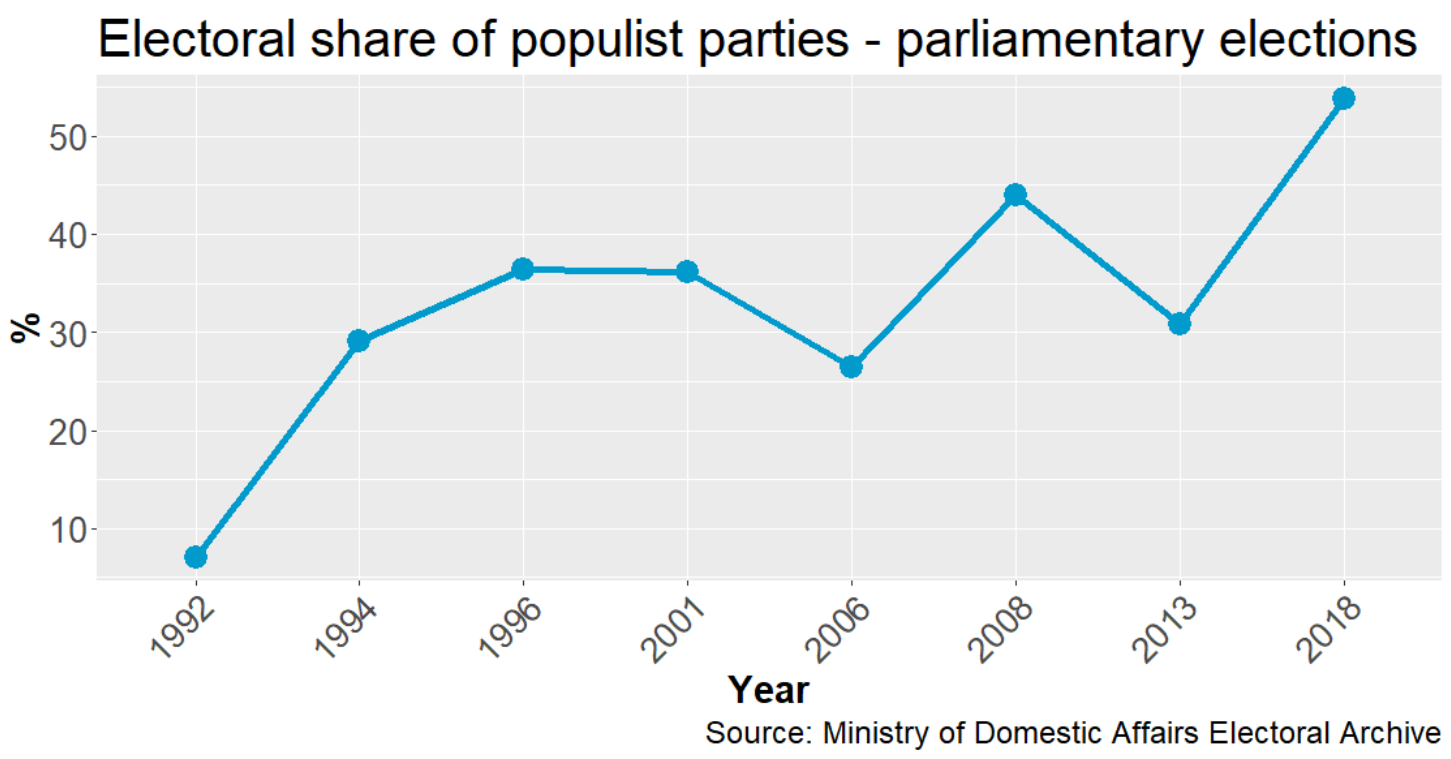

Italy has a long and varied history of party system instability and has experienced several significant populist or anti-system parties. To add to the complexity, some parties emerge as anti-system forces and then become identified with the mainstream. We classify populist parties drawing on The PopuList (M. Rooduijn et al. 2019) and complement this by analyzing the formal programmatic documents of the key parties. The Democratic Party (and its antecedents since the abandonment of the Communist label in 1991) is a centre-left establishment party, Forza Italia is a right-populist party in its initial phase but we code it as a centre-right mainstream party after the Global Financial Crisis (ie from the 2013 election, the first after the crisis). The Northern League (or League from 2018) is coded as right-populist for the whole period of its history (it entered parliament in 1992), as well as the Brothers of Italy-National Alliance. The Five Star Movement is also populist for its whole history (it entered parliament in 2013), and we coded it as left-populist (whilst recognizing its ideological ambiguity; see Hopkin 2020, Ch.7). 
Figure 2

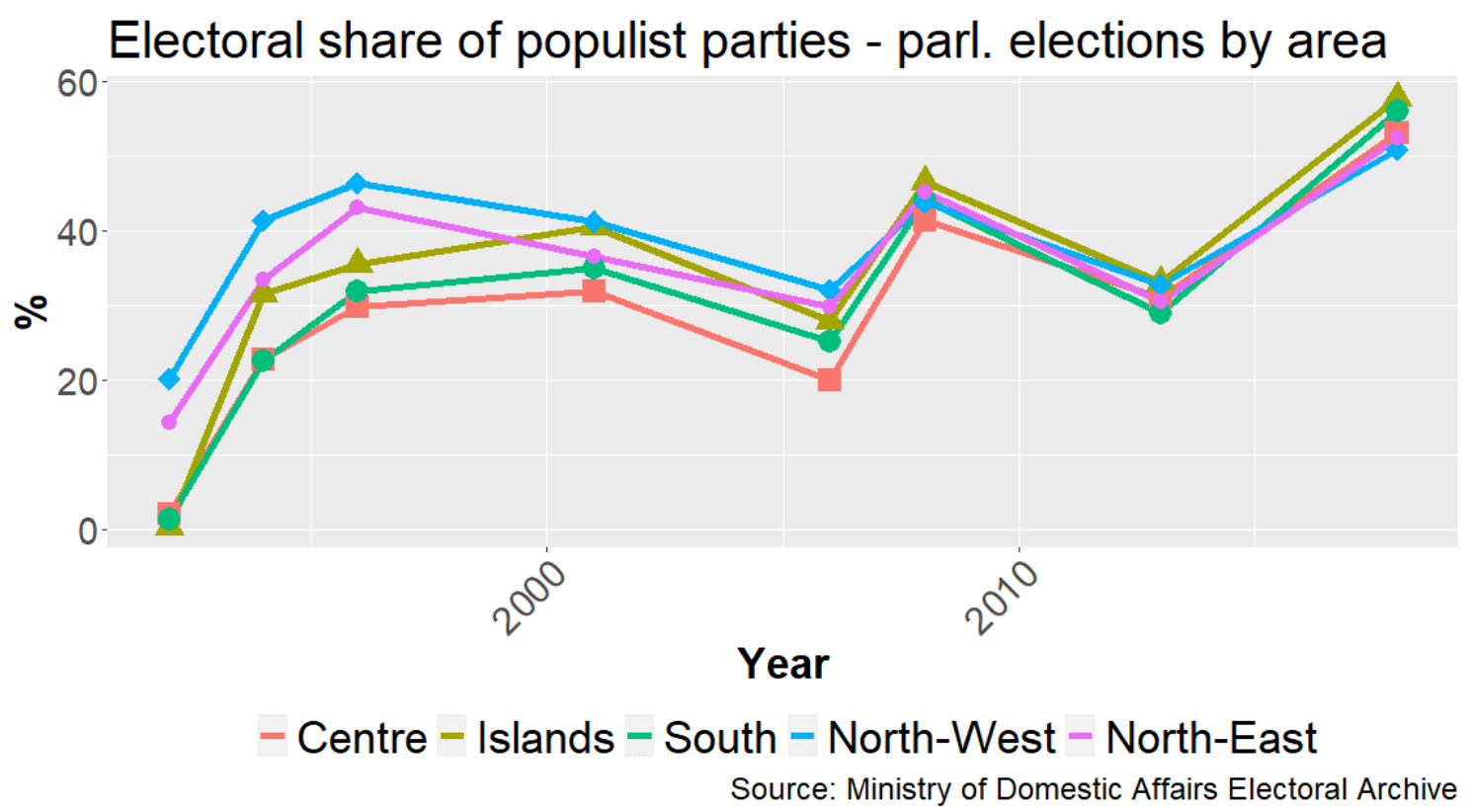

The policy positions adopted by these parties reflect this classification. The League's position evolved from being opposed to austerity in 2013 but not fiercely Eurosceptic, proposes that ECB should act as lender of last resort; and supporting banking/fiscal union and euro-bonds. In terms of domestic policy, the League proposed more "family-oriented" fiscal policies using equivalent income-based taxes (using a family weight depending on the size), abolishing property tax on primary residences, abolishing wealth tax, opposing VAT increases, and arguing for lower taxes overall and streamlined tax bureaucracy for small- and medium-sized businesses. Alongside these typical positions for right-wing parties, the League adopted a skeptical attitude to the banking sector advocating easier credit and the protection of bank depositors instead of shareholders, etc. By 2018, the party had adopted the policy of a "Flat tax", and more lax treatment of tax irregularities and tax liabilities of individuals. At the same time the League proposed easing retirement rules and facilitating access to pensions on the basis of age instead of contributions, reversing the pensions cuts implemented in 2012 (Fornero's law). The League had also become more decisively Eurosceptic, urging the reneging of recent treaties and a return to the pre-Maastricht arrangements.

The Five Star Movement is a more difficult object to classify. In its first election campaign in 2013 the party programme - a wafer-thin document only 15 pages long had little to say on economic policy, beyond reversing labour market and unemployment compensation reforms, and some measures to protect corporate and stock market insider-dealing. By 2018, its focus on political corruption had expanded to include concerns over recent high profile bank failures, and contained some strong anti-bank rhetoric. The 2018 programme also adopted a clearly anti-EU tone, rejecting austerity 
Figure 3
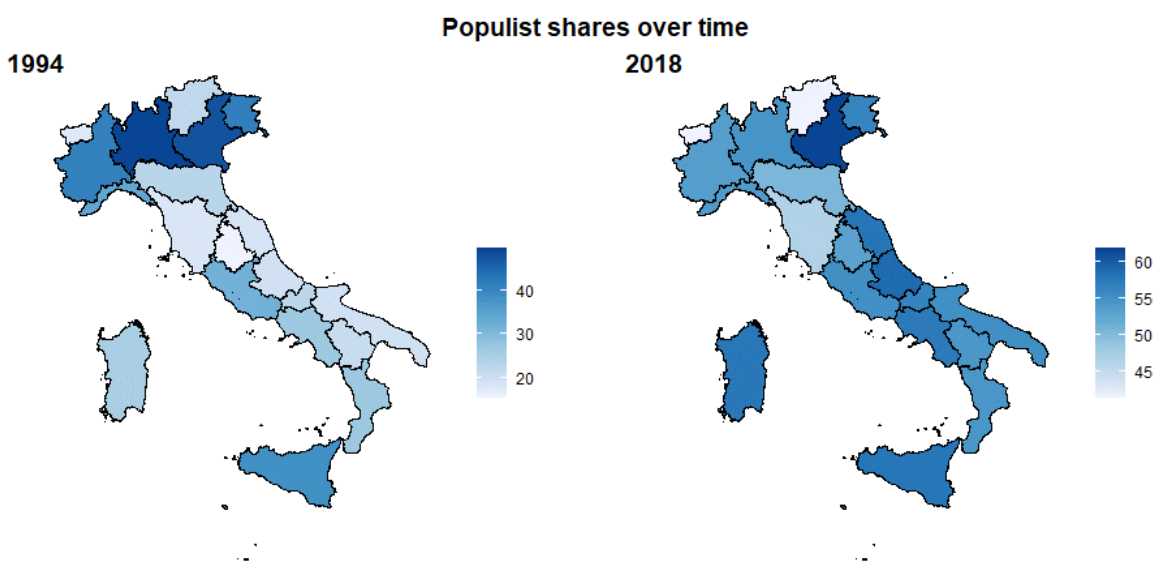

Data source: Ministry of Domestic Affairs's Historical Electoral Archive

measures and the inteferences in Italian policy coming from the European Commission and the European Central Bank. On other issues, like the League Five Stars advocated a reduction in the tax burden, but skewed in favour of individual wage-earners rather than the small business and self-employed groups favoured by the right. Moreover Five Stars argued for redistribution of wealth to the weakest economic strata. Despite its reluctance to align with any ideology or locate itself on the Left-Right spectrum the Five Star Movement lacks the typical features of right-wing populism and adopts some clearly progressive and redistributive positions, matching its following amongst younger and lower income voters.

For financial and economic variables we make use of the Bank of Italy's Survey on Household Income and Wealth (SHIW), using waves from 1987 to 2016, to develop a number of variables capturing the influence of household wealth, leverage, and financial vulnerability. SHIW provides the highest quality source of comprehensive information in Italy on wealth, income, leverage, and other socio-economic characteristics of a representative sample of households and individuals interviewed at two-year intervals (Bloise, Chironi, and Pianta 2019). To fill missing years we have performed cubic spline interpolation between 1987 and 2016, and then imputed last year's values up to 2018, in order to assess the 2018 elections. The sample in more recent surveys comprises approximately 8,000 households (20,000 individuals), distributed across Italy's regions in roughly 300 municipalities. All variables are lagged one year with respect to election years.

For housing assets we utilize the mean self-reported value of residential property holdings within regions. We measure average net household wealth in regions as per the SHIW definition, i.e. as the sum of real and financial assets, excluding financial liabilities. We measure mortgage debt using the SHIW variable capturing the "amount of debts owed at the end of the year to banks or financial companies for the purchase or restructuring of housing properties", at the household level. We take the natural 
$\log$ of each of these three variables.

We also consider the amount of financial assets held in shares, bonds, and private pensions and the share of each region owning these assets. To capture the amount of shares we use the SHIW variable measuring the "amount of shares (of listed and unlisted companies) held at the end of the year at the household level", generating the mean at regional level. We also generate the percentage of households "holding shares at the end of the year". We make use of the SHIW variable capturing the amount of "bonds held at the end of the year" at the household level, taking its mean at regional level. We also create a variable measuring the percentage of households "holding bonds at the end of the year". To measure the amount of private pensions we made use of the SHIW variable capturing the "amount paid for private/supplementary pensions, annuities and other forms of insurance-based saving", generating the mean at regional level. Furthermore, we calculate the percentage of households with a non-missing, positive amount of this variable to measure the percentage of households with a private pension.

We generate variables to capture household financial stress, following the Bank of Italy's definitions (Banca d'Italia 2018) in creating variables measuring the share of financially vulnerable households and the share of wealth-poor households. We measure the former as the share of households with monetary income below the median (at the regional level) and debt service payments equal to more than $30 \%$ of their income. We follow the Bank of Italy in capturing the latter as the share of households with wealth - in the form of easily liquidated financial assets, adjusted to take into account the structure of the household - below one fourth of the national "at-risk-of-poverty threshold" (60\% of median equivalent income).

We also include a number of control variables from the SHIW dataset: the natural log of net wages, the percentage of female voters, the unemployment rate, the percentage of university-educated voters, and age and its quadratic form. All of these variables are taken as means at the regional level. A measure of the China import shock at the regional level is included, as defined by Colantone and Stanig (2018b), i.e. as the sum, by industry, of the ratio of the number of workers in a region over the total number of workers in the same region, both measured at the beginning of the sample, multiplied by the ratio of the change in real imports from China in a given industry over the number of workers in the industry, the latter measured at the beginning of the sample period. Data for occupation have been retrieved from Istat, while data for imports have been retrieved from Eurostat Comext.

\section{Results}

We estimate a panel fixed effects model, allowing for autocorrelation within regions with robust standard errors clustered at the regional level. All models include a lagged dependent variable (LDV) and a dummy variable to capture the crisis period, starting 
in 2008. Tables 2 and 3 present the results of the models for populist parties using levels; table 4 reports the results of the models benchmarked against the previous maximum value; table 5 against the value at the previous election.

We find consistent evidence that both house price levels and changes are connected to voters' relative support for populist parties in Italy. We see negative effects on support for populist parties of higher mean house price levels and higher house price growth since the previous maximum value (levels) and the previous election (growth). In other words, regions with higher house price levels and growth were less supportive of populist parties.

Higher house prices and house price growth are likely linked to more optimistic "climates of fortune" (the "geotropic effect") as well as to the accumulation of wealth in housing assets, particularly among middle class home owners (the "pocketbook effect"). Populist policies may pose a threat to these voters in these regions. On the other hand, lower house price levels and house price depreciation likely fuels resentment of local or regional decline while at the same time generating pocketbook wealth losses for home owners. Such regional dynamics appear to prompt demands for more radical change and to favour populism.

Real assets constituted $87 \%$ of household gross wealth for Italian households in 2016 (Banca d'Italia 2018, pp. 5-6). Of this, the value of owner-occupied homes is the main component of the wealth portfolio for Italian households, except for the lowest quintile. Financial wealth constitutes about 10 percent of total household wealth on average, and nearly 20 percent for the wealthiest five percent. As such, we would expect similar results when we substitute levels and changes in mean net household wealth for house prices. Like house prices, levels of net household wealth should proxy for local perceptions of long-run economic fortune within regions, whereas changes should capture straightforward pocketbook effects. The results in tables $2-5$ confirm these expectations. Regions with higher levels and growth of net household wealth are less supportive of populist parties.

Household leverage is also connected to populist voting in most of the models. Mortgage debt constitutes the largest component of household leverage. Our analysis suggests regions with higher levels of mortgage debt are less likely to support populist parties. We find similar results when we consider a broader measure that includes all household financial liabilities. The results suggest higher levels of household debt may heighten voter anxiety about the risks that populist parties pose to the value leveraged assets and to the volume and cost of credit.

Turning to market-traded financial assets, we find some evidence that populist voting is negatively related to value of bond holdings and private pension assets and to the share of households owning bonds. As with housing assets, voters in regions with higher levels of bond and private pension assets and bond ownership may have perceived populist parties as posing a threat to their wealth holdings. For some voters, these concerns were realized when pressure on asset prices followed the populist electoral victory in 2018. However, these relationships fail to attain statistical significance in models where we consider import shock. 
Interestingly, the share of households owning private pension assets is positively related to populist voting in models when we include import shock. However, this result is unlikely to be due to the inclusion of import shock alone, which recall restricts our analysis to elections from 2001 onwards. In separate model specifications, we find a positive and significant coefficient when we exclude the import shock variable and restrict the sample to elections from 2001 onwards as well as from 1996 onwards.

Figure 4

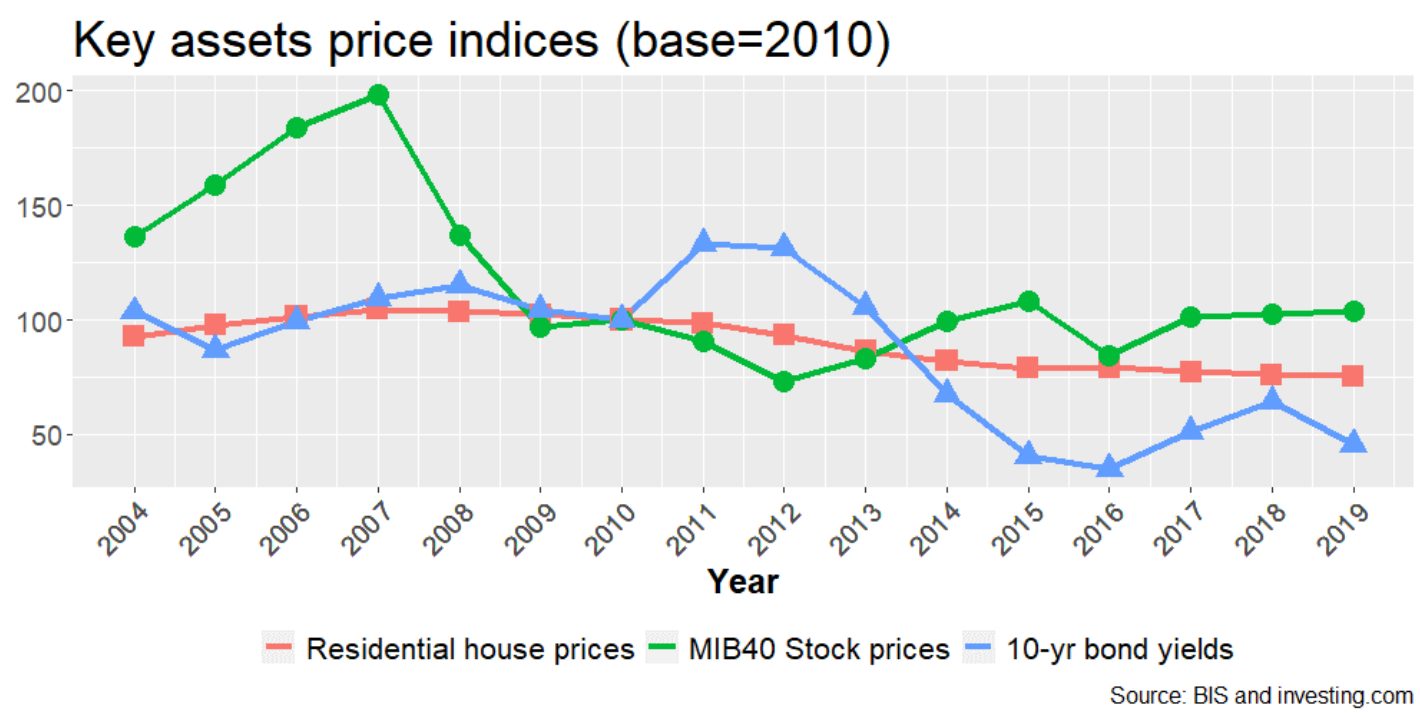

Neither of our measures of household financial stress - the share of financially vulnerable households and share of wealth-poor households - was statistically significant. As opposed to wealth anxiety, which appears to drive middle class and wealthier households toward mainstream parties, there appears to be no consensus among the financially vulnerable for populist parties. This may reflect the very different factors that drive voting for the League and for the 5SM. We turn to these factors below.

Briefly turning to the control variables, we find consistent support for the expected relationships for the import shock and the crisis-period. Along with the crisis-period, regions with higher levels of exposure to the import shock are likely to have greater support for populist parties. There is also some evidence that populist parties receive greater support in regions with higher levels of unemployment. In some models we find age and age-squared to be significant. The negative coefficient for age and positive coefficient for age-squared indicates the curve of non-linear effect for age is convex. Put differently, "younger" and "older" regions tend to vote for populists but regions in the intermediate "middle" age do not. Lastly, we also find that net wage growth in regions since the previous election heightens support for populist parties.

As discussed, the League and 5SM offer contrasting policy positions on a number of different issues and thus voting for these parties is likely driven by different factors. These parties have emerged as the principal challenge to the mainstream parties of the 
Second Republic. The League has contested elections in some regions since 1992 and in all regions since 2013. We thus include a lagged dependent variable in these models. The 5SM has only contested the two most recent elections in 2013 and 2018, which precludes the use of a lagged dependent variable. We present the League results in Tables $6-9$, and those for the 5SM in Tables $10-13$. We also provide results for the far right, defined as League and Brothers of Italy in Tables 14-17. The results from these tables may be summarized as follows.

First, higher house prices and house price growth are negatively related to vote share of both parties. We find similar results when we substitute average net wealth of households in regions for house prices. Regions with lower levels of and growth in house prices and net wealth are those where the League and 5SM appear to attract a higher vote share. This is consistent with the argument that relative wealth deprivation fosters resentment in declining regions and populist voting. Mainstream parties, however, appear to perform better in regions with higher levels of and growth in house prices and net wealth.

Second, household debt is connected to voting for both parties, but in contrasting ways in some of the models. Regions with higher levels of mortgage debt are consistently less likely to support 5SM. However, the League is likely to enjoy greater support in more highly leveraged regions, though this result is limited to models where we include import shock and in separate model specifications when we import shock and restrict the sample to elections from 2001 onwards. This result likely stems from the differential treatment these parties give to taxation of property wealth and debt.

Third, we also find contrasting effects for levels and ownership of some financial assets. While votes for the 5SM increase in regions where share ownership is more prevalent, the League tends to receive fewer votes in such regions as well as in regions where bond ownership is more widespread, though the latter result holds only in models where we exclude import shock. This may be related to the 5SM's vocal attacks on insider-dealing in stock markets and the alleged corruption in some processes of privatization which could be plausibly linked to some financial losses.

Fourth, financial vulnerability emerges as an important factor shaping voting for the 5SM. The share of votes for the 5SM increases as the share of financially vulnerable households in a region rises. The share of financially vulnerable households in higher in the South, which is the area where 5SM draws its strongest support.

Lastly, regarding the control variables, we find League voting is associated with import shock and a non-linear convex effect for age. The 5SM tends to receive a higher share of votes in regions with higher levels of unemployment. Both parties receive a higher share of votes in regions with a larger share of female voters. 


\section{Conclusions}

Thus far our analysis of Italy is suggestive of a connection between financial shocks, financial distress more broadly, and the rise of populist voting as hypothesized. The relatively robust support for mainstream parties in regions where housing wealth has been less affected by financial crises confirms our expectation that wealthier parts of the electorate are more invested in the status quo, supporting parties that have demonstrated their commitment to fiscal and monetary orthodoxy and rejecting populist challenges to continued participation in European Monetary Union. As expected, ownership of financial assets is also predictive of support for mainstream parties.

Some results were less obviously consistent with our hypotheses, notably the relationship between populist voting and the share of voters owning private pension assets, which remain a smaller share of pension income in Italy than in the Anglo-American democracies, but a growing one. Voters with more pensions assets are less likely to vote for populist parties, however. The other finding which conformed less cleanly to our expectations is the lack of a significant relationship between financial distress and populist voting. This suggests the need to consider more carefully our theoretical expectations regarding the different forms that anti-establishment political responses can take.

In the Italian case, large populist movements have emerged both on the right and the left of the mainstream parties, and non-economic factors, for example historical patterns of voting that influence the availability of voters for one or the other populist party, may confound these relationships. The next stage in this project is to develop more precise estimates of how different aspects of the financial status of households can be expected to shape their electoral behaviour under conditions of economic uncertainty. 


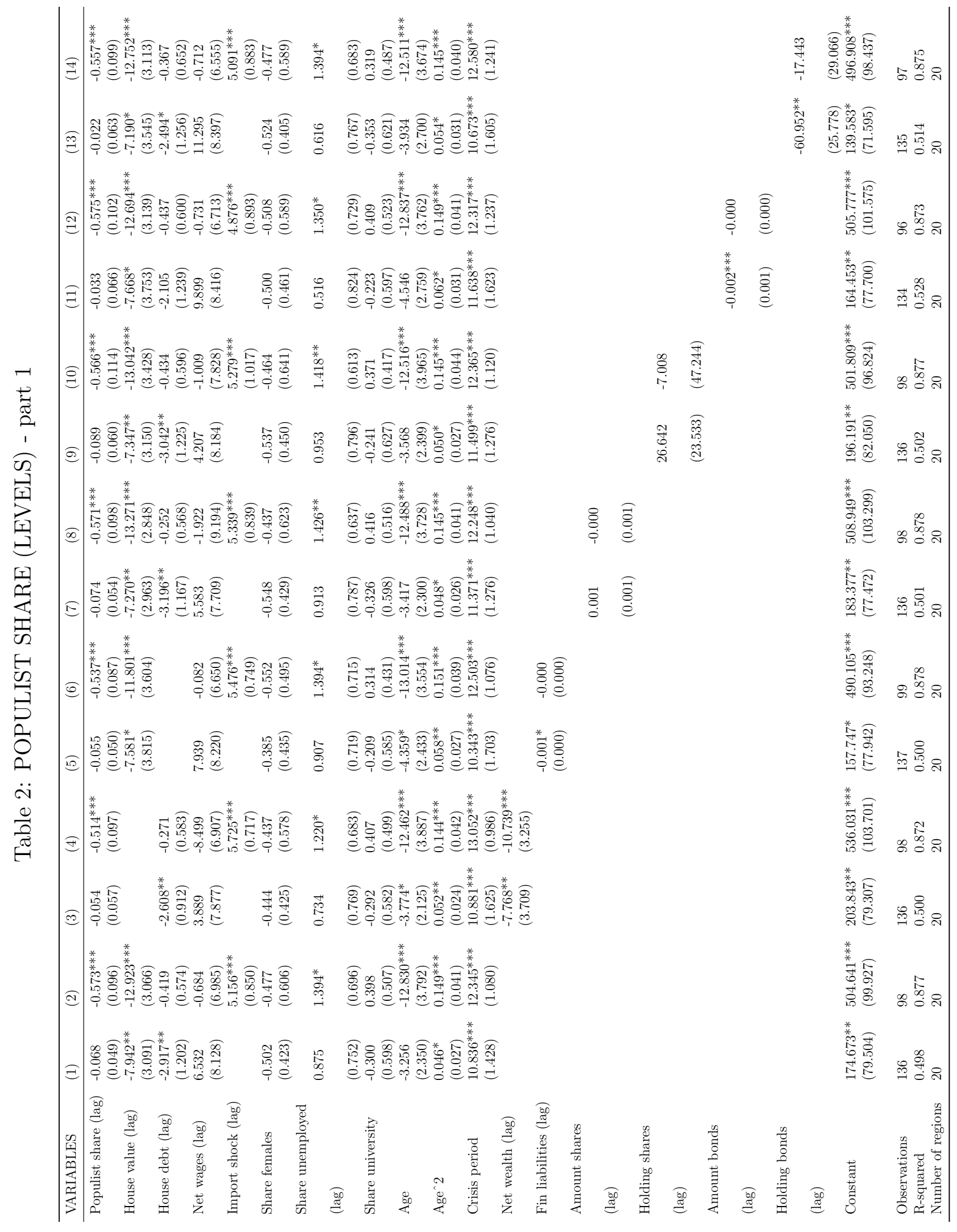




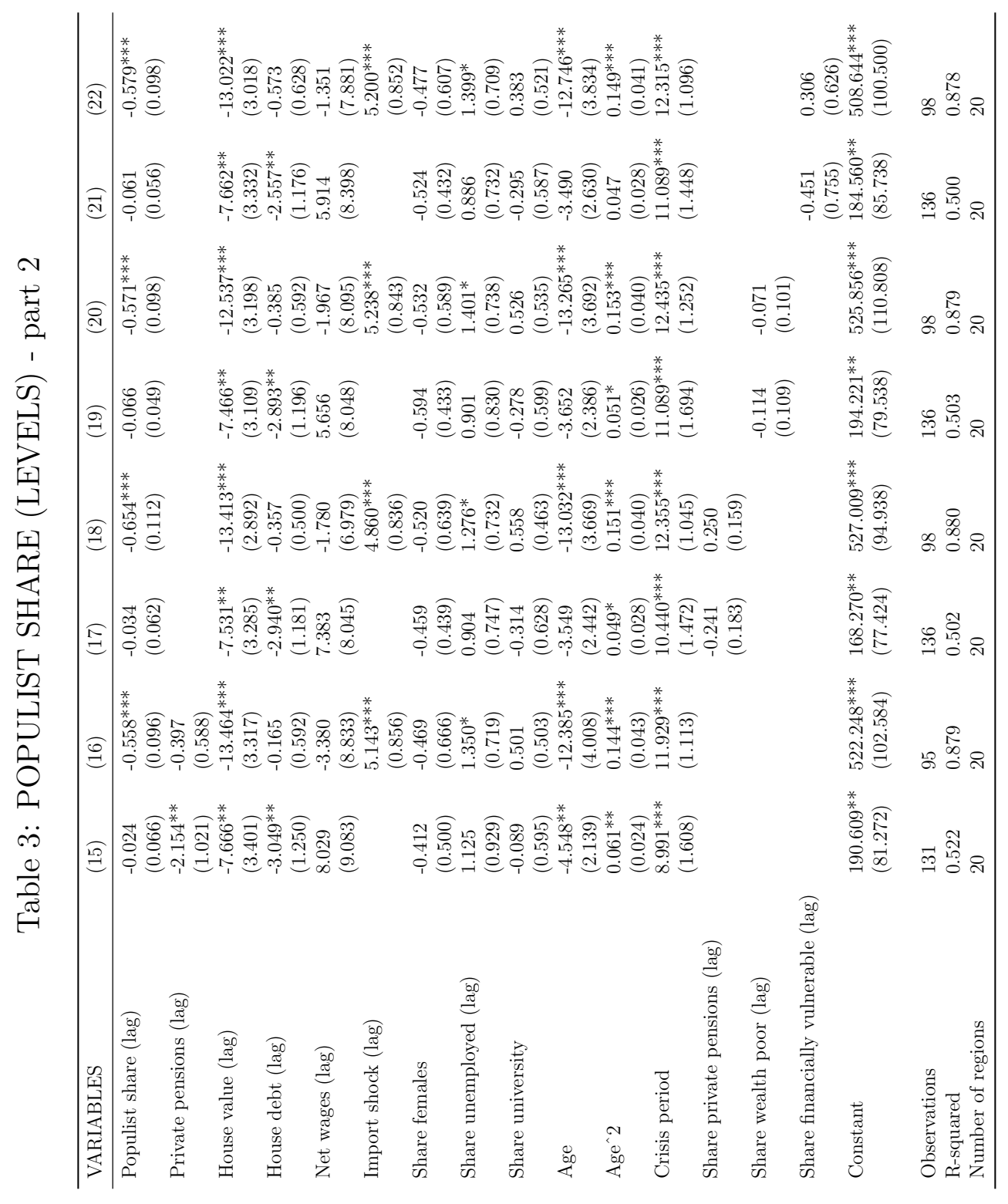




\section{Table 4: POPULIST SHARE, CHANGES SINCE MAX}

\begin{tabular}{|c|c|c|c|c|c|c|}
\hline VARIABLES & (1) & $(2)$ & $(3)$ & (4) & $(5)$ & (6) \\
\hline Populist share (lag) & $\begin{array}{c}-0.122^{* *} \\
(0.048)\end{array}$ & $\begin{array}{c}-0.516^{* * *} \\
(0.094)\end{array}$ & $\begin{array}{c}-0.126^{* *} \\
(0.047)\end{array}$ & $\begin{array}{c}-0.458^{* * *} \\
(0.095)\end{array}$ & $\begin{array}{c}-0.122^{* *} \\
(0.050)\end{array}$ & $\begin{array}{c}-0.464^{* * *} \\
(0.085)\end{array}$ \\
\hline House value change since max (lag) & $\begin{array}{c}-19.367^{* *} \\
(7.091)\end{array}$ & $\begin{array}{c}-27.766^{* * *} \\
(5.942)\end{array}$ & & & $\begin{array}{c}-15.524^{* *} \\
(7.154)\end{array}$ & $\begin{array}{c}-25.876^{* * * *} \\
(6.024)\end{array}$ \\
\hline House debt change since max (lag) & $\begin{array}{c}-2.604^{* *} \\
(1.037)\end{array}$ & $\begin{array}{l}-0.696 \\
(0.507)\end{array}$ & $\begin{array}{c}-2.149^{* *} \\
(0.868)\end{array}$ & $\begin{array}{l}-0.687 \\
(0.603)\end{array}$ & & \\
\hline Net wages since max (lag) & $\begin{array}{l}12.337 \\
(8.834)\end{array}$ & $\begin{array}{c}0.017 \\
(6.698)\end{array}$ & $\begin{array}{c}7.788 \\
(8.539)\end{array}$ & $\begin{array}{l}-7.804 \\
(9.128)\end{array}$ & $\begin{array}{l}10.934 \\
(8.606)\end{array}$ & $\begin{array}{c}0.912 \\
(7.033)\end{array}$ \\
\hline Import shock (lag) & & $\begin{array}{c}6.763^{* * *} \\
(0.819)\end{array}$ & & $\begin{array}{c}7.059^{* * *} \\
(0.796)\end{array}$ & & $\begin{array}{c}7.208^{* * *} \\
(0.789)\end{array}$ \\
\hline Share females & $\begin{array}{l}-0.343 \\
(0.430)\end{array}$ & $\begin{array}{l}-0.294 \\
(0.373)\end{array}$ & $\begin{array}{l}-0.198 \\
(0.483)\end{array}$ & $\begin{array}{l}-0.374 \\
(0.435)\end{array}$ & $\begin{array}{l}-0.015 \\
(0.428)\end{array}$ & $\begin{array}{l}-0.291 \\
(0.355)\end{array}$ \\
\hline Share unemployed (lag) & $\begin{array}{c}0.877 \\
(0.728)\end{array}$ & $\begin{array}{l}1.123^{*} \\
(0.591)\end{array}$ & $\begin{array}{c}0.836 \\
(0.798)\end{array}$ & $\begin{array}{l}1.146 \\
(0.751)\end{array}$ & $\begin{array}{l}1.036 \\
(0.701)\end{array}$ & $\begin{array}{l}1.143^{*} \\
(0.594)\end{array}$ \\
\hline Share university & $\begin{array}{l}-0.721 \\
(0.604)\end{array}$ & $\begin{array}{c}0.103 \\
(0.393)\end{array}$ & $\begin{array}{l}-0.747 \\
(0.609)\end{array}$ & $\begin{array}{c}0.071 \\
(0.524)\end{array}$ & $\begin{array}{l}-0.630 \\
(0.599)\end{array}$ & $\begin{array}{c}0.083 \\
(0.375)\end{array}$ \\
\hline Age & $\begin{array}{l}-4.376^{*} \\
(2.404)\end{array}$ & $\begin{array}{c}-12.802^{* * *} \\
(3.102)\end{array}$ & $\begin{array}{l}-3.717 \\
(2.261)\end{array}$ & $\begin{array}{c}-12.181^{* * *} \\
(3.457)\end{array}$ & $\begin{array}{c}-6.143^{* *} \\
(2.424)\end{array}$ & $\begin{array}{c}-12.907^{* * *} \\
(2.992)\end{array}$ \\
\hline Age^2 & $\begin{array}{l}0.056^{*} \\
(0.028)\end{array}$ & $\begin{array}{c}0.144^{* * *} \\
(0.034)\end{array}$ & $\begin{array}{l}0.048^{*} \\
(0.026)\end{array}$ & $\begin{array}{c}0.138^{* * *} \\
(0.039)\end{array}$ & $\begin{array}{c}0.073^{* *} \\
(0.028)\end{array}$ & $\begin{array}{c}0.146^{* * *} \\
(0.033)\end{array}$ \\
\hline Crisis period & $\begin{array}{c}7.101^{* * *} \\
(1.306)\end{array}$ & $\begin{array}{c}8.752^{* * *} \\
(1.229)\end{array}$ & $\begin{array}{c}7.781^{* * *} \\
(1.501)\end{array}$ & $\begin{array}{c}10.679^{* * *} \\
(1.236)\end{array}$ & $\begin{array}{c}6.947^{* * *} \\
(1.384)\end{array}$ & $\begin{array}{c}9.180 * * * \\
(1.191)\end{array}$ \\
\hline Net wealth change since max (lag) & & & $\begin{array}{c}-15.261^{* * *} \\
(4.326)\end{array}$ & $\begin{array}{c}-13.012^{* * *} \\
(3.453)\end{array}$ & & \\
\hline Financial liabilities change since $\max$ (lag) & & & & & $\begin{array}{c}-7.817^{* *} \\
(3.049)\end{array}$ & $\begin{array}{l}-3.157 \\
(1.970)\end{array}$ \\
\hline Constant & $\begin{array}{c}141.147^{* * *} \\
(46.960)\end{array}$ & $\begin{array}{c}338.982^{* * *} \\
(74.271)\end{array}$ & $\begin{array}{c}119.759^{* *} \\
(47.808)\end{array}$ & $\begin{array}{c}322.891^{* * *} \\
(82.514)\end{array}$ & $\begin{array}{c}165.873^{* * *} \\
(45.151)\end{array}$ & $\begin{array}{c}337.384^{* * *} \\
(73.231)\end{array}$ \\
\hline Observations & 136 & 98 & 136 & 98 & 137 & 99 \\
\hline R-squared & 0.499 & 0.897 & 0.510 & 0.875 & 0.514 & 0.899 \\
\hline Number of regions & 20 & 20 & 20 & 20 & 20 & 20 \\
\hline
\end{tabular}




\section{Table 5: POPULIST SHARE, CHANGES SINCE PREVIOUS ELECTIONS}

\begin{tabular}{|c|c|c|c|c|c|c|}
\hline VARIABLES & (1) & (2) & (3) & (4) & $(5)$ & (6) \\
\hline Populist share (lag) & $\begin{array}{c}-0.132^{* *} \\
(0.047)\end{array}$ & $\begin{array}{c}-0.464^{* * * *} \\
(0.085)\end{array}$ & $\begin{array}{c}-0.117^{* *} \\
(0.049)\end{array}$ & $\begin{array}{c}-0.395^{* * * *} \\
(0.108)\end{array}$ & $\begin{array}{c}-0.141 * * * \\
(0.044)\end{array}$ & $\begin{array}{c}-0.488 * * * \\
(0.077)\end{array}$ \\
\hline House value change since prev elect (lag) & $\begin{array}{c}-14.636^{* * *} \\
(3.962)\end{array}$ & $\begin{array}{c}-15.125^{* * *} \\
(2.647)\end{array}$ & & & $\begin{array}{c}-13.519^{* * *} \\
(4.443)\end{array}$ & $\begin{array}{c}-14.815^{* * * *} \\
(3.104)\end{array}$ \\
\hline House debt change since prev elect (lag) & $\begin{array}{c}-1.900^{* *} \\
(0.796)\end{array}$ & $\begin{array}{l}-0.737 \\
(0.494)\end{array}$ & $\begin{array}{c}-2.088^{* *} \\
(0.772)\end{array}$ & $\begin{array}{c}-1.271^{*} \\
(0.734)\end{array}$ & & \\
\hline Net wages change since prev elect (lag) & $\begin{array}{c}30.819 * * * \\
(6.400)\end{array}$ & $\begin{array}{c}16.739^{* *} \\
(7.525)\end{array}$ & $\begin{array}{c}26.018^{* * *} \\
(6.730)\end{array}$ & $\begin{array}{c}13.446^{*} \\
(7.368)\end{array}$ & $\begin{array}{c}29.576^{* * *} \\
(5.827)\end{array}$ & $\begin{array}{c}16.040^{* *} \\
(6.784)\end{array}$ \\
\hline Import shock (lag) & & $\begin{array}{c}5.994 * * * \\
(0.643)\end{array}$ & & $\begin{array}{c}6.522^{* * *} \\
(0.684)\end{array}$ & & $\begin{array}{c}5.822^{* * *} \\
(0.593)\end{array}$ \\
\hline Share females & $\begin{array}{l}-0.550 \\
(0.547)\end{array}$ & $\begin{array}{l}-0.627 \\
(0.438)\end{array}$ & $\begin{array}{l}-0.398 \\
(0.572)\end{array}$ & $\begin{array}{l}-0.532 \\
(0.477)\end{array}$ & $\begin{array}{l}-0.209 \\
(0.479)\end{array}$ & $\begin{array}{l}-0.384 \\
(0.413)\end{array}$ \\
\hline Share unemployed (lag) & $\begin{array}{c}0.759 \\
(0.595)\end{array}$ & $\begin{array}{c}0.923 \\
(0.548)\end{array}$ & $\begin{array}{c}0.840 \\
(0.605)\end{array}$ & $\begin{array}{l}1.218^{* *} \\
(0.561)\end{array}$ & $\begin{array}{l}0.999^{*} \\
(0.565)\end{array}$ & $\begin{array}{l}1.038^{*} \\
(0.586)\end{array}$ \\
\hline Share university & $\begin{array}{l}-0.811 \\
(0.539)\end{array}$ & $\begin{array}{c}0.002 \\
(0.430)\end{array}$ & $\begin{array}{l}-0.958 \\
(0.556)\end{array}$ & $\begin{array}{l}-0.272 \\
(0.482)\end{array}$ & $\begin{array}{l}-0.676 \\
(0.531)\end{array}$ & $\begin{array}{c}0.136 \\
(0.446)\end{array}$ \\
\hline Age & $\begin{array}{c}-5.898^{* * * *} \\
(1.970)\end{array}$ & $\begin{array}{c}-15.636^{* * *} \\
(3.144)\end{array}$ & $\begin{array}{c}-6.364 * * * \\
(1.986)\end{array}$ & $\begin{array}{c}-15.263^{* * *} \\
(3.266)\end{array}$ & $\begin{array}{c}-6.993^{* * *} * \\
(2.005)\end{array}$ & $\begin{array}{c}-17.285^{* * * *} \\
(3.180)\end{array}$ \\
\hline $\operatorname{Age}^{\wedge} 2$ & $\begin{array}{c}0.078^{* * * *} \\
(0.023)\end{array}$ & $\begin{array}{c}0.184^{* * *} \\
(0.035)\end{array}$ & $\begin{array}{c}0.082^{* * * *} \\
(0.024)\end{array}$ & $\begin{array}{c}0.178^{* * * *} \\
(0.036)\end{array}$ & $\begin{array}{c}0.089^{* * *} * \\
(0.023)\end{array}$ & $\begin{array}{c}0.200^{* * *} \\
(0.036)\end{array}$ \\
\hline Crisis period & $\begin{array}{c}6.975^{* * *} \\
(1.711)\end{array}$ & $\begin{array}{c}7.746^{* * * *} \\
(1.410)\end{array}$ & $\begin{array}{c}9.123^{* * *} \\
(1.748)\end{array}$ & $\begin{array}{c}11.504^{* * *} \\
(1.669)\end{array}$ & $\begin{array}{c}7.522^{* * *} \\
(1.842)\end{array}$ & $\begin{array}{c}7.726^{* * *} \\
(1.367)\end{array}$ \\
\hline Net wealth change since prev elect (lag) & & & $\begin{array}{l}-8.799^{*} \\
(4.572)\end{array}$ & $\begin{array}{c}-5.848^{* *} \\
(2.476)\end{array}$ & & \\
\hline Financial liabilities change since prev elect (lag) & & & & & $\begin{array}{l}-0.640 \\
(1.015)\end{array}$ & $\begin{array}{l}-0.056 \\
(0.571)\end{array}$ \\
\hline Constant & $\begin{array}{c}176.472^{* * * *} \\
(44.433)\end{array}$ & $\begin{array}{c}404.487^{* * *} \\
\quad(78.509)\end{array}$ & $\begin{array}{c}182.027^{* * *} \\
(47.871)\end{array}$ & $\begin{array}{c}389.846^{* * *} \\
(80.996)\end{array}$ & $\begin{array}{c}184.125 * * * \\
(37.973)\end{array}$ & $\begin{array}{c}431.419^{* * *} \\
(77.636)\end{array}$ \\
\hline Observations & 136 & 98 & 136 & 98 & 137 & 99 \\
\hline R-squared & 0.564 & 0.896 & 0.554 & 0.874 & 0.548 & 0.891 \\
\hline Number of regions & 20 & 20 & 20 & 20 & 20 & 20 \\
\hline
\end{tabular}




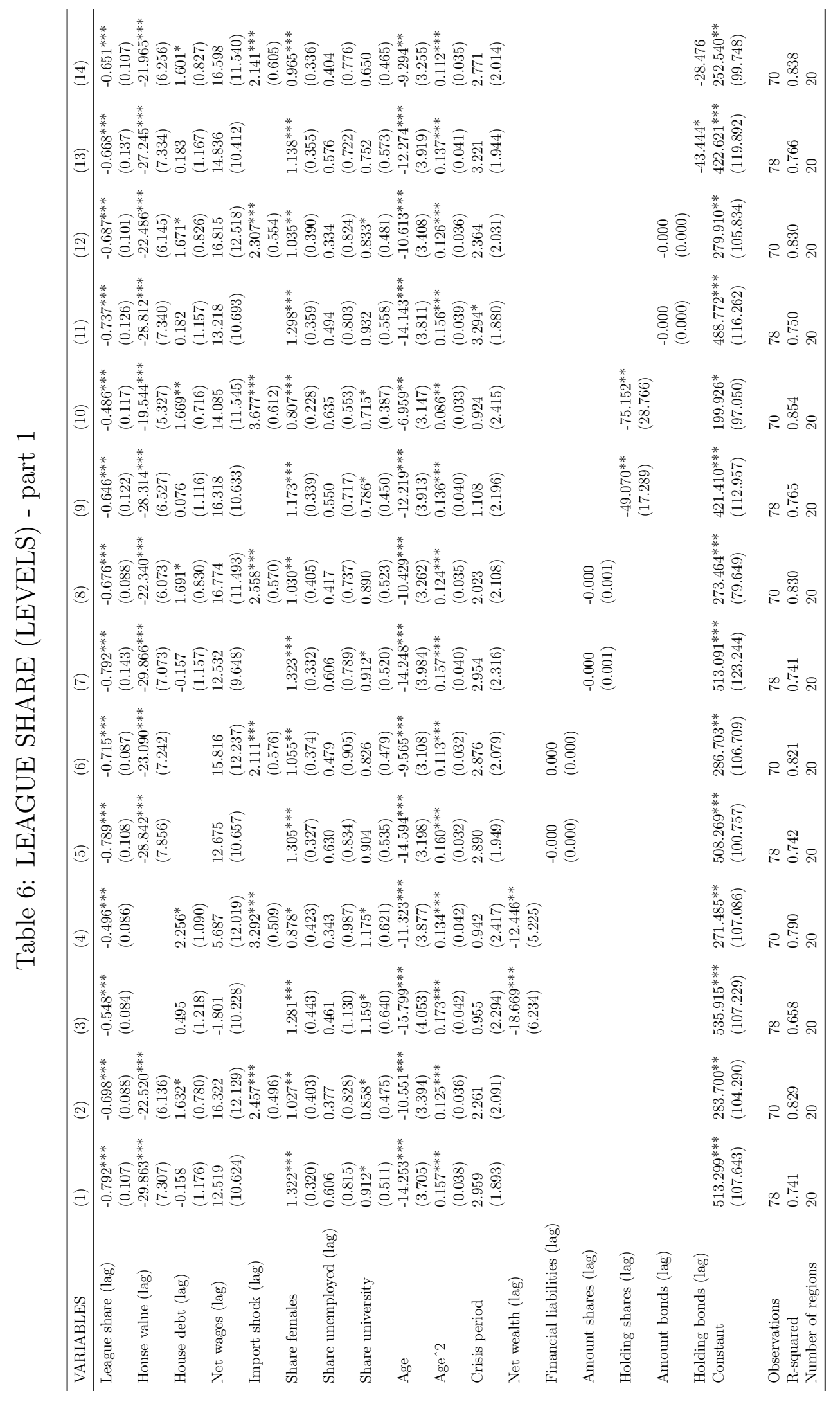




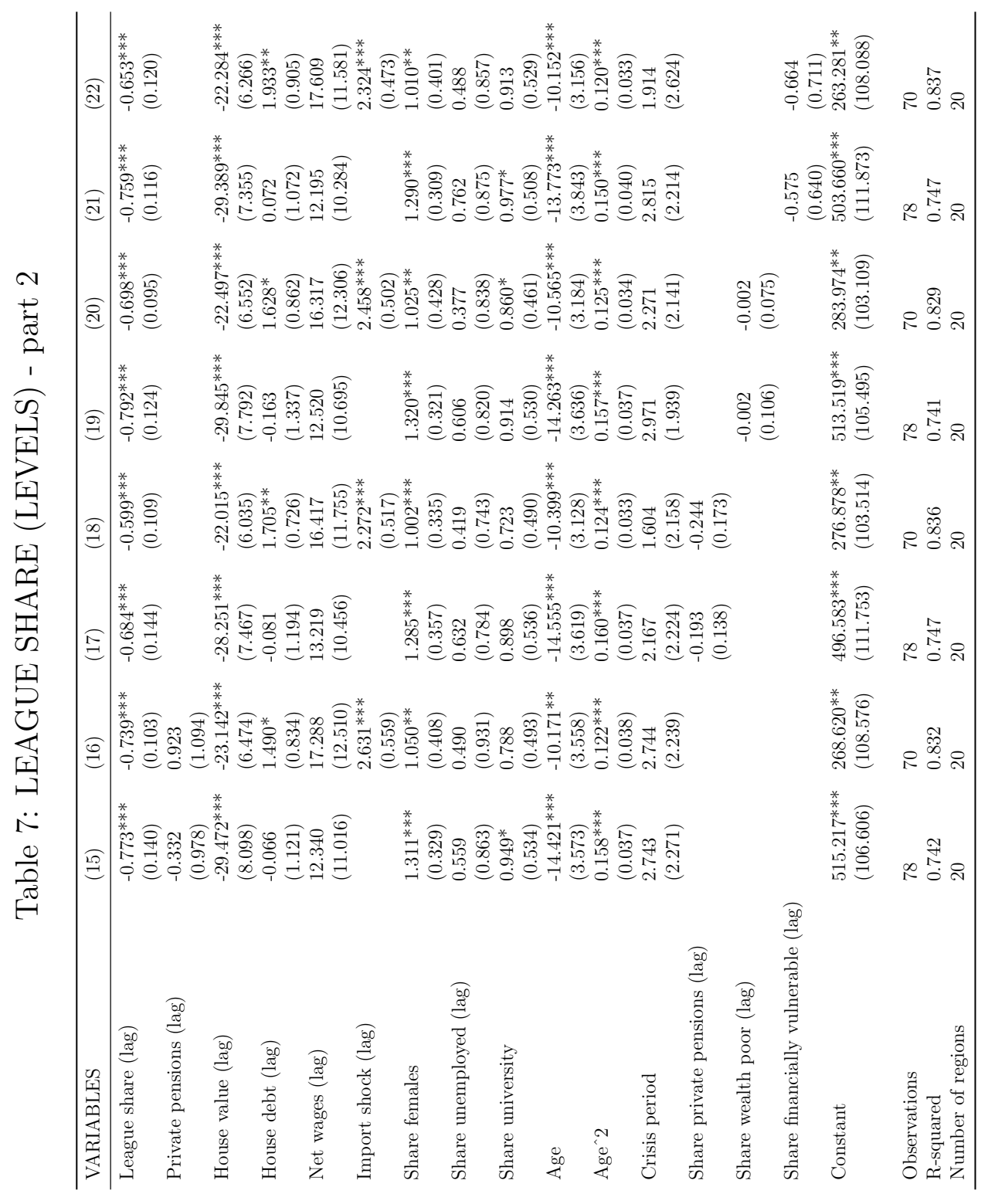




\section{Table 8: LEAGUE SHARE, CHANGES SINCE MAX}

\begin{tabular}{|c|c|c|c|c|c|c|}
\hline VARIABLES & (1) & $(2)$ & (3) & (4) & (5) & (6) \\
\hline League share (lag) & $\begin{array}{c}-0.486^{* * *} \\
(0.111)\end{array}$ & $\begin{array}{c}-0.532^{* * *} \\
(0.065)\end{array}$ & $\begin{array}{c}-0.465^{* * *} \\
(0.114)\end{array}$ & $\begin{array}{c}-0.504^{* * *} \\
(0.074)\end{array}$ & $\begin{array}{c}-0.474^{* * *} \\
(0.115)\end{array}$ & $\begin{array}{c}-0.529 * * * \\
(0.063)\end{array}$ \\
\hline House value change since $\max$ (lag) & $\begin{array}{c}-18.518^{* * *} \\
(5.856)\end{array}$ & $\begin{array}{c}-18.221^{* * *} \\
(6.239)\end{array}$ & & & $\begin{array}{c}-15.452^{*} \\
(7.862)\end{array}$ & $\begin{array}{c}-16.308^{* *} \\
(7.739)\end{array}$ \\
\hline House debt change since max (lag) & $\begin{array}{l}-1.051 \\
(1.084)\end{array}$ & $\begin{array}{c}0.682 \\
(0.824)\end{array}$ & $\begin{array}{l}-0.317 \\
(1.112)\end{array}$ & $\begin{array}{c}1.637 \\
(1.137)\end{array}$ & & \\
\hline Net wages change since $\max$ (lag) & $\begin{array}{c}-8.868 \\
(13.522)\end{array}$ & $\begin{array}{c}-5.760 \\
(10.646)\end{array}$ & $\begin{array}{l}-15.263 \\
(13.395)\end{array}$ & $\begin{array}{l}-11.129 \\
(13.061)\end{array}$ & $\begin{array}{c}-8.510 \\
(13.732)\end{array}$ & $\begin{array}{c}-6.922 \\
(10.175)\end{array}$ \\
\hline Import shock (lag) & & $\begin{array}{c}3.984^{* * *} \\
(0.487)\end{array}$ & & $\begin{array}{c}4.063^{* * *} \\
(0.431)\end{array}$ & & $\begin{array}{c}3.921^{* * *} * \\
(0.506)\end{array}$ \\
\hline Share females & $\begin{array}{c}0.832 \\
(0.620)\end{array}$ & $\begin{array}{c}0.622 \\
(0.378)\end{array}$ & $\begin{array}{c}0.804 \\
(0.576)\end{array}$ & $\begin{array}{c}0.598 \\
(0.403)\end{array}$ & $\begin{array}{c}0.908 \\
(0.661)\end{array}$ & $\begin{array}{c}0.581 \\
(0.356)\end{array}$ \\
\hline Share unemployed (lag) & $\begin{array}{c}1.025 \\
(0.764)\end{array}$ & $\begin{array}{c}0.723 \\
(0.629)\end{array}$ & $\begin{array}{c}1.104 \\
(0.931)\end{array}$ & $\begin{array}{c}0.715 \\
(0.803)\end{array}$ & $\begin{array}{c}1.129 \\
(0.879)\end{array}$ & $\begin{array}{c}0.856 \\
(0.674)\end{array}$ \\
\hline Share university & $\begin{array}{l}-0.177 \\
(0.499)\end{array}$ & $\begin{array}{l}0.821^{*} \\
(0.466)\end{array}$ & $\begin{array}{c}0.083 \\
(0.547)\end{array}$ & $\begin{array}{l}1.189^{*} \\
(0.623)\end{array}$ & $\begin{array}{l}-0.085 \\
(0.523)\end{array}$ & $\begin{array}{l}0.761^{*} \\
(0.418)\end{array}$ \\
\hline Age & $\begin{array}{c}-17.061^{* * *} \\
(4.661)\end{array}$ & $\begin{array}{c}-8.200^{* * *} \\
(2.797)\end{array}$ & $\begin{array}{c}-17.735^{* * *} \\
(4.742)\end{array}$ & $\begin{array}{c}-8.440^{* *} \\
(3.540)\end{array}$ & $\begin{array}{c}-18.393^{* * *} \\
(4.378)\end{array}$ & $\begin{array}{c}-8.284^{* * *} \\
(2.525)\end{array}$ \\
\hline Age^2 & $\begin{array}{c}0.182^{* * *} \\
(0.048)\end{array}$ & $\begin{array}{c}0.095^{* * * *} \\
(0.031)\end{array}$ & $\begin{array}{c}0.190 * * * \\
(0.050)\end{array}$ & $\begin{array}{c}0.099 * * \\
(0.039)\end{array}$ & $\begin{array}{c}0.196^{* * *} \\
(0.044)\end{array}$ & $\begin{array}{c}0.094^{* * *} \\
(0.027)\end{array}$ \\
\hline Crisis period & $\begin{array}{l}-1.124 \\
(1.473)\end{array}$ & $\begin{array}{c}0.076 \\
(2.129)\end{array}$ & $\begin{array}{l}-1.177 \\
(1.927)\end{array}$ & $\begin{array}{l}-0.266 \\
(2.584)\end{array}$ & $\begin{array}{l}-1.470 \\
(1.347)\end{array}$ & $\begin{array}{c}0.313 \\
(2.023)\end{array}$ \\
\hline Net wealth change since max (lag) & & & $\begin{array}{l}-7.554 \\
(6.655)\end{array}$ & $\begin{array}{l}-9.020^{*} \\
(5.096)\end{array}$ & & \\
\hline Financial liabilities change since max (lag) & & & & & $\begin{array}{l}-3.039 \\
(3.098)\end{array}$ & $\begin{array}{l}-1.478 \\
(2.731)\end{array}$ \\
\hline Constant & $\begin{array}{c}364.686^{* * *} \\
(107.543)\end{array}$ & $\begin{array}{c}139.421^{* *} \\
(59.670)\end{array}$ & $\begin{array}{c}376.353^{* * *} \\
(107.952)\end{array}$ & $\begin{array}{c}139.812^{*} \\
(68.186)\end{array}$ & $\begin{array}{c}390.448^{* * *} \\
(100.603)\end{array}$ & $\begin{array}{c}146.615^{* *} \\
(59.361)\end{array}$ \\
\hline Observations & 78 & 70 & 78 & 70 & 78 & 70 \\
\hline R-squared & 0.571 & 0.800 & 0.547 & 0.783 & 0.574 & 0.800 \\
\hline Number of regions & 20 & 20 & 20 & 20 & 20 & 20 \\
\hline
\end{tabular}




\section{Table 9: LEAGUE SHARE, CHANGES SINCE PREVIOUS ELECTIONS}

\begin{tabular}{|c|c|c|c|c|c|c|}
\hline VARIABLES & $(1)$ & $(2)$ & $(3)$ & $(4)$ & $(5)$ & $(6)$ \\
\hline Share League (lag) & $\begin{array}{c}-0.510^{* * *} \\
(0.089)\end{array}$ & $\begin{array}{c}-0.503^{* * *} \\
(0.062)\end{array}$ & $\begin{array}{c}-0.403^{* * *} \\
(0.112)\end{array}$ & $\begin{array}{c}-0.446 * * * \\
(0.066)\end{array}$ & $\begin{array}{c}-0.512^{* * *} \\
(0.094)\end{array}$ & $\begin{array}{c}-0.504^{* * *} \\
(0.061)\end{array}$ \\
\hline House value change since prev elect (lag) & $\begin{array}{c}-14.942^{* *} \\
(5.530)\end{array}$ & $\begin{array}{l}-7.619 \\
(5.179)\end{array}$ & & & $\begin{array}{c}-16.271 * * * \\
(4.803)\end{array}$ & $\begin{array}{l}-8.026 \\
(5.178)\end{array}$ \\
\hline House debt change since prev elect (lag) & $\begin{array}{l}-0.607 \\
(1.308)\end{array}$ & $\begin{array}{l}-0.127 \\
(1.254)\end{array}$ & $\begin{array}{l}-0.956 \\
(1.295)\end{array}$ & $\begin{array}{l}-0.454 \\
(1.466)\end{array}$ & & \\
\hline Net wages change since prev elect (lag) & $\begin{array}{c}9.491 \\
(7.875)\end{array}$ & $\begin{array}{l}11.164 \\
(7.925)\end{array}$ & $\begin{array}{c}4.990 \\
(7.570)\end{array}$ & $\begin{array}{c}8.896 \\
(7.463)\end{array}$ & $\begin{array}{l}10.599 \\
(7.397)\end{array}$ & $\begin{array}{l}11.514 \\
(8.708)\end{array}$ \\
\hline Import shock (lag) & & $\begin{array}{c}3.025^{* * *} \\
(0.626)\end{array}$ & & $\begin{array}{c}3.095^{* * *} \\
(0.639)\end{array}$ & & $\begin{array}{c}3.010^{* * *} \\
(0.628)\end{array}$ \\
\hline Share females & $\begin{array}{c}0.436 \\
(0.736)\end{array}$ & $\begin{array}{c}0.344 \\
(0.352)\end{array}$ & $\begin{array}{c}0.405 \\
(0.713)\end{array}$ & $\begin{array}{c}0.339 \\
(0.378)\end{array}$ & $\begin{array}{c}0.474 \\
(0.743)\end{array}$ & $\begin{array}{c}0.358 \\
(0.351)\end{array}$ \\
\hline Share unemployed (lag) & $\begin{array}{c}0.845 \\
(0.946)\end{array}$ & $\begin{array}{c}0.480 \\
(0.880)\end{array}$ & $\begin{array}{c}1.226 \\
(1.010)\end{array}$ & $\begin{array}{c}0.725 \\
(0.810)\end{array}$ & $\begin{array}{c}0.659 \\
(0.866)\end{array}$ & $\begin{array}{c}0.405 \\
(0.982)\end{array}$ \\
\hline Share university & $\begin{array}{c}0.005 \\
(0.466)\end{array}$ & $\begin{array}{c}0.769 \\
(0.561)\end{array}$ & $\begin{array}{c}0.033 \\
(0.490)\end{array}$ & $\begin{array}{c}0.794 \\
(0.559)\end{array}$ & $\begin{array}{c}0.071 \\
(0.475)\end{array}$ & $\begin{array}{c}0.784 \\
(0.553)\end{array}$ \\
\hline Age & $\begin{array}{c}-18.375^{* * *} \\
(4.182)\end{array}$ & $\begin{array}{c}-9.728^{* * * *} \\
(2.892)\end{array}$ & $\begin{array}{c}-18.238^{* * *} \\
(4.826)\end{array}$ & $\begin{array}{c}-9.524^{* * *} \\
(3.091)\end{array}$ & $\begin{array}{c}-19.131^{* * *} \\
(3.672)\end{array}$ & $\begin{array}{c}-9.939^{* * * *} \\
(3.369)\end{array}$ \\
\hline Age`2 $^{\wedge}$ & $\begin{array}{c}0.203^{* * *} \\
(0.044)\end{array}$ & $\begin{array}{c}0.117^{* * *} \\
(0.031)\end{array}$ & $\begin{array}{c}0.200 * * * \\
(0.051)\end{array}$ & $\begin{array}{c}0.114^{* * * *} \\
(0.034)\end{array}$ & $\begin{array}{c}0.211^{* * *} \\
(0.038)\end{array}$ & $\begin{array}{c}0.120^{* * *} \\
(0.037)\end{array}$ \\
\hline Crisis period & $\begin{array}{l}-2.940 \\
(1.832)\end{array}$ & $\begin{array}{c}0.671 \\
(2.327)\end{array}$ & $\begin{array}{l}-1.143 \\
(2.043)\end{array}$ & $\begin{array}{c}1.872 \\
(2.288)\end{array}$ & $\begin{array}{c}-3.140 \\
(1.839)\end{array}$ & $\begin{array}{c}0.601 \\
(2.322)\end{array}$ \\
\hline Net wealth change since prev elect & & & $\begin{array}{c}-8.236 \\
(4.919)\end{array}$ & $\begin{array}{l}-3.096 \\
(3.187)\end{array}$ & & \\
\hline Financial liabilities change since prev elect & & & & & $\begin{array}{c}-0.032 \\
(0.612)\end{array}$ & $\begin{array}{c}0.084 \\
(0.469)\end{array}$ \\
\hline Constant & $\begin{array}{c}402.513^{* * *} \\
(105.805)\end{array}$ & $\begin{array}{c}178.709 * * * \\
(59.885)\end{array}$ & $\begin{array}{c}401.156 * * * \\
(116.628)\end{array}$ & $\begin{array}{c}173.787^{* *} \\
(63.785)\end{array}$ & $\begin{array}{c}417.364^{* * * *} \\
(94.044)\end{array}$ & $\begin{array}{c}182.571^{* *} \\
(68.948)\end{array}$ \\
\hline Observations & 78 & 70 & 78 & 70 & 78 & 70 \\
\hline R-squared & 0.575 & 0.777 & 0.556 & 0.770 & 0.573 & 0.777 \\
\hline Number of regions & 20 & 20 & 20 & 20 & 20 & 20 \\
\hline
\end{tabular}




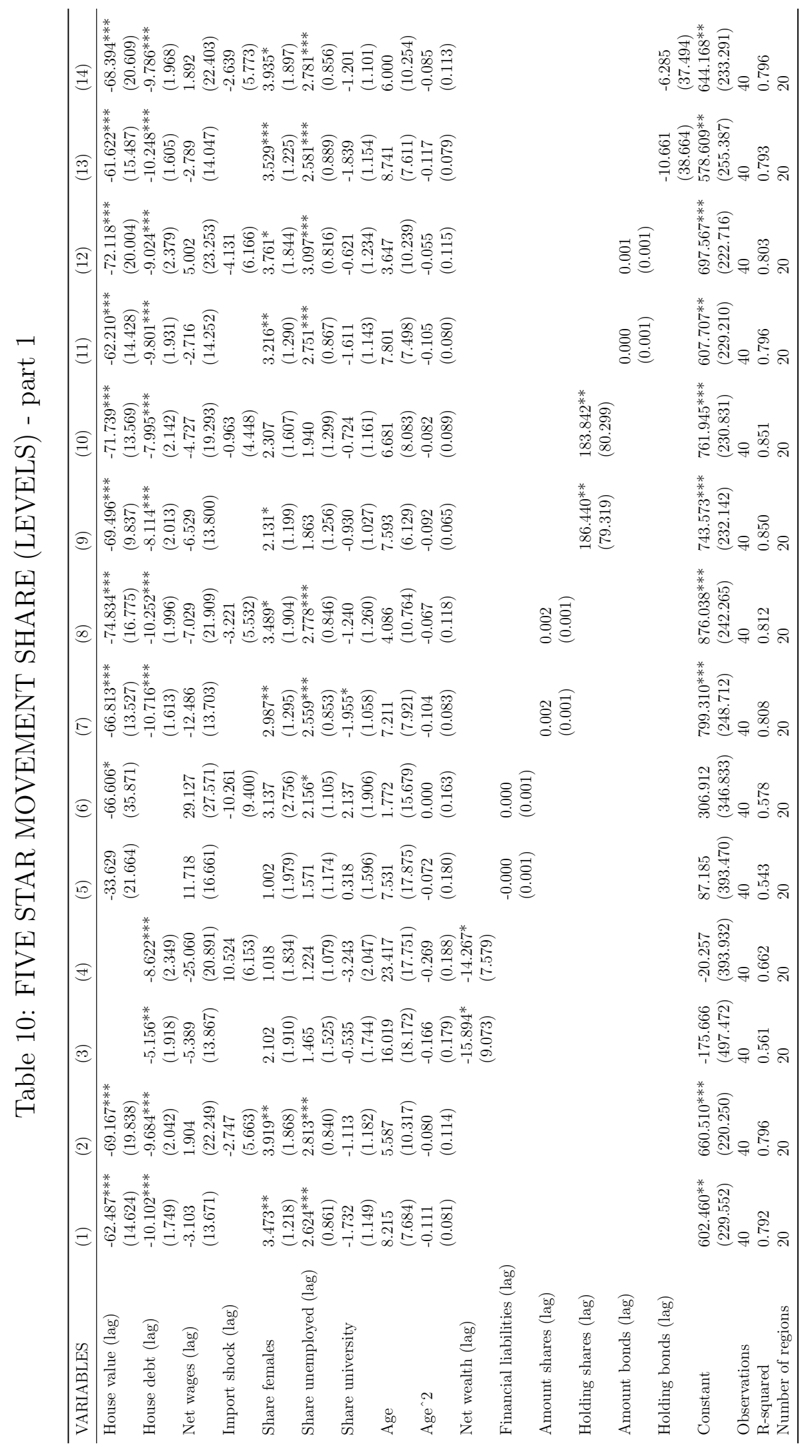




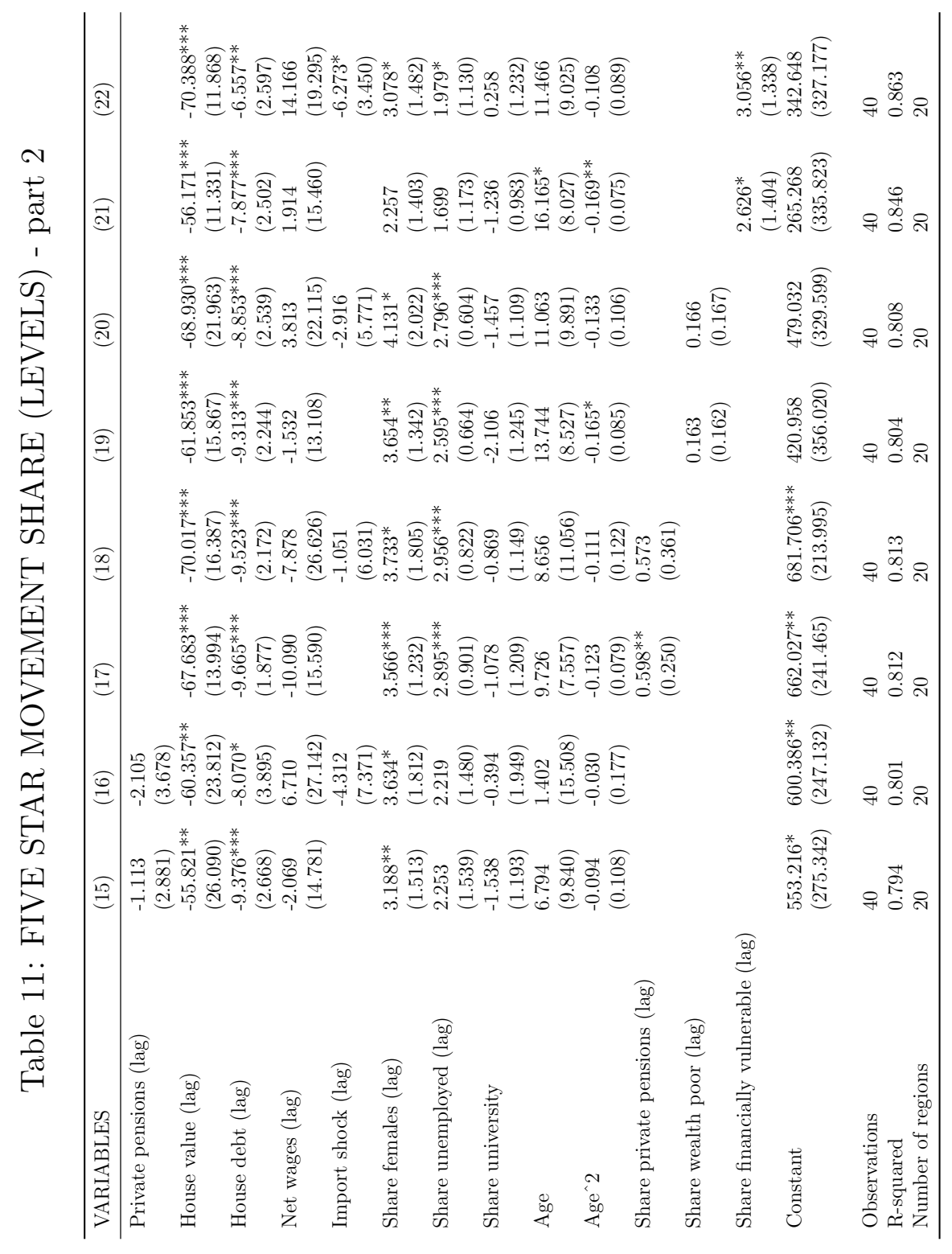




\section{Table 12: FIVE STAR MOVEMENT SHARE, CHANGES SINCE MAX}

\begin{tabular}{|c|c|c|c|c|c|c|}
\hline VARIABLES & (1) & $(2)$ & (3) & (4) & (5) & (6) \\
\hline House value change since $\max$ (lag) & $\begin{array}{c}-63.536 * * * \\
(13.061)\end{array}$ & $\begin{array}{c}-66.916^{* * *} \\
(16.659)\end{array}$ & & & $\begin{array}{l}-27.823 \\
(21.916)\end{array}$ & $\begin{array}{l}-43.669 \\
(34.082)\end{array}$ \\
\hline House debt change since max (lag) & $\begin{array}{c}-11.959^{* * *} \\
(1.471)\end{array}$ & $\begin{array}{c}-11.676^{* * *} \\
(2.115)\end{array}$ & $\begin{array}{c}-6.059^{* * *} \\
(2.088)\end{array}$ & $\begin{array}{c}-10.666^{* * *} \\
(2.513)\end{array}$ & & \\
\hline Net wages change since max (lag) & $\begin{array}{l}-15.120 \\
(12.891)\end{array}$ & $\begin{array}{c}-12.052 \\
(23.262)\end{array}$ & $\begin{array}{c}-8.179 \\
(17.302)\end{array}$ & $\begin{array}{l}-35.788 \\
(22.415)\end{array}$ & $\begin{array}{c}9.590 \\
(20.873)\end{array}$ & $\begin{array}{c}19.080 \\
(32.060)\end{array}$ \\
\hline Import shock (lag) & & $\begin{array}{l}-1.392 \\
(5.301)\end{array}$ & & $\begin{array}{c}11.201 * \\
(5.961)\end{array}$ & & $\begin{array}{l}-4.777 \\
(7.735)\end{array}$ \\
\hline Share females & $\begin{array}{c}3.724^{* * *} \\
(0.928)\end{array}$ & $\begin{array}{c}3.930^{* *} \\
(1.533)\end{array}$ & $\begin{array}{c}1.933 \\
(1.975)\end{array}$ & $\begin{array}{l}1.015 \\
(1.788)\end{array}$ & $\begin{array}{c}0.540 \\
(1.619)\end{array}$ & $\begin{array}{l}1.566 \\
(2.106)\end{array}$ \\
\hline Share unemployed (lag) & $\begin{array}{c}2.901^{* * *} \\
(0.735)\end{array}$ & $\begin{array}{c}2.994^{* * *} \\
(0.669)\end{array}$ & $\begin{array}{c}1.580 \\
(1.482)\end{array}$ & $\begin{array}{l}1.386 \\
(0.944)\end{array}$ & $\begin{array}{l}2.110^{*} \\
(1.215)\end{array}$ & $\begin{array}{l}2.384^{*} \\
(1.182)\end{array}$ \\
\hline Share university & $\begin{array}{c}-2.402^{* *} \\
(0.971)\end{array}$ & $\begin{array}{l}-2.047^{*} \\
(1.149)\end{array}$ & $\begin{array}{l}-0.952 \\
(1.593)\end{array}$ & $\begin{array}{l}-4.325^{*} \\
(2.133)\end{array}$ & $\begin{array}{c}0.674 \\
(1.493)\end{array}$ & $\begin{array}{c}1.577 \\
(1.891)\end{array}$ \\
\hline Age & $\begin{array}{c}8.975 \\
(7.259)\end{array}$ & $\begin{array}{c}7.482 \\
(10.450)\end{array}$ & $\begin{array}{c}16.052 \\
(18.100)\end{array}$ & $\begin{array}{c}25.150 \\
(17.772)\end{array}$ & $\begin{array}{c}4.714 \\
(15.317)\end{array}$ & $\begin{array}{c}0.702 \\
(15.990)\end{array}$ \\
\hline Age`2 $^{\wedge}$ & $\begin{array}{l}-0.128 \\
(0.078)\end{array}$ & $\begin{array}{l}-0.110 \\
(0.118)\end{array}$ & $\begin{array}{l}-0.170 \\
(0.179)\end{array}$ & $\begin{array}{l}-0.295 \\
(0.190)\end{array}$ & $\begin{array}{l}-0.048 \\
(0.157)\end{array}$ & $\begin{array}{l}-0.001 \\
(0.169)\end{array}$ \\
\hline Net wealth change since max (lag) & & & $\begin{array}{l}-12.753 \\
(8.081)\end{array}$ & $\begin{array}{l}-9.609 \\
(6.144)\end{array}$ & & \\
\hline Financial liabilities change since max (lag) & & & & & $\begin{array}{c}-11.875^{* *} \\
(4.963)\end{array}$ & $\begin{array}{l}-9.440 \\
(7.429)\end{array}$ \\
\hline Constant & $\begin{array}{c}-299.332^{*} \\
(162.329)\end{array}$ & $\begin{array}{c}-283.624 \\
(183.435)\end{array}$ & $\begin{array}{l}-451.416 \\
(414.925)\end{array}$ & $\begin{array}{c}-513.528 \\
(355.155)\end{array}$ & $\begin{array}{l}-138.205 \\
(356.600)\end{array}$ & $\begin{array}{c}-120.450 \\
(346.721)\end{array}$ \\
\hline Observations & 40 & 40 & 40 & 40 & 40 & 40 \\
\hline R-squared & 0.829 & 0.830 & 0.570 & 0.682 & 0.623 & 0.632 \\
\hline Number of regions & 20 & 20 & 20 & 20 & 20 & 20 \\
\hline
\end{tabular}

Table 13: FIVE STAR MOVEMENT SHARE, CHANGES SINCE PREVIOUS ELECTIONS

\begin{tabular}{|c|c|c|c|c|c|c|}
\hline VARIABLES & (1) & $(2)$ & (3) & (4) & $(5)$ & (6) \\
\hline House value change since prev elect (lag) & $\begin{array}{c}-53.291^{* * *} \\
(13.979)\end{array}$ & $\begin{array}{c}-62.622^{* * *} \\
(8.507)\end{array}$ & & & $\begin{array}{c}-62.893^{* * *} \\
(5.840)\end{array}$ & $\begin{array}{l}-69.149^{* * *} \\
\quad(5.777)\end{array}$ \\
\hline House debt change since prev elect (lag) & $\begin{array}{c}-5.055^{* *} \\
(1.992)\end{array}$ & $\begin{array}{l}-1.362 \\
(3.297)\end{array}$ & $\begin{array}{l}-4.426 \\
(3.141)\end{array}$ & $\begin{array}{l}-6.269 \\
(4.717)\end{array}$ & & \\
\hline Net wealth change since prev elect (lag) & $\begin{array}{c}21.897^{* *} \\
(8.187)\end{array}$ & $\begin{array}{c}41.823^{* *} \\
(15.114)\end{array}$ & $\begin{array}{c}19.016 \\
(14.119)\end{array}$ & $\begin{array}{c}9.463 \\
(21.278)\end{array}$ & $\begin{array}{c}27.962^{* * * *} \\
(5.890)\end{array}$ & $\begin{array}{c}37.018^{* * *} \\
(5.946)\end{array}$ \\
\hline Import shock (lag) & & $\begin{array}{l}-8.037 \\
(5.048)\end{array}$ & & $\begin{array}{l}3.754 \\
(6.773)\end{array}$ & & $\begin{array}{c}-5.801^{* * *} \\
(1.649)\end{array}$ \\
\hline Share females & $\begin{array}{c}4.246^{* * *} \\
(1.444)\end{array}$ & $\begin{array}{c}4.847^{* * *} \\
(1.592)\end{array}$ & $\begin{array}{c}2.487 \\
(1.848)\end{array}$ & $\begin{array}{l}2.486 \\
(1.798)\end{array}$ & $\begin{array}{l}1.760 \\
(1.135)\end{array}$ & $\begin{array}{c}3.184^{* *} \\
(1.127)\end{array}$ \\
\hline Share unemployed (lag) & $\begin{array}{l}1.988^{*} \\
(1.062)\end{array}$ & $\begin{array}{c}0.886 \\
(1.473)\end{array}$ & $\begin{array}{l}1.706 \\
(1.677)\end{array}$ & $\begin{array}{l}2.305 \\
(1.874)\end{array}$ & $\begin{array}{c}1.540^{* * *} \\
(0.238)\end{array}$ & $\begin{array}{c}1.566^{* * *} \\
(0.283)\end{array}$ \\
\hline Share university & $\begin{array}{l}-0.892 \\
(1.396)\end{array}$ & $\begin{array}{c}0.792 \\
(1.247)\end{array}$ & $\begin{array}{l}-1.884 \\
(1.811)\end{array}$ & $\begin{array}{l}-2.413 \\
(2.103)\end{array}$ & $\begin{array}{l}1.056^{*} \\
(0.514)\end{array}$ & $\begin{array}{l}1.814^{* *} \\
(0.678)\end{array}$ \\
\hline Age & $\begin{array}{c}8.209 \\
(8.993)\end{array}$ & $\begin{array}{c}-1.719 \\
(10.626)\end{array}$ & $\begin{array}{c}24.149 \\
(14.281)\end{array}$ & $\begin{array}{c}27.804 \\
(17.000)\end{array}$ & $\begin{array}{c}2.096 \\
(7.622)\end{array}$ & $\begin{array}{c}-3.131 \\
(6.064)\end{array}$ \\
\hline $\operatorname{Age}^{\wedge} 2$ & $\begin{array}{l}-0.090 \\
(0.092)\end{array}$ & $\begin{array}{c}0.032 \\
(0.121)\end{array}$ & $\begin{array}{c}-0.247^{*} \\
(0.140)\end{array}$ & $\begin{array}{l}-0.296 \\
(0.181)\end{array}$ & $\begin{array}{l}-0.022 \\
(0.078)\end{array}$ & $\begin{array}{c}0.040 \\
(0.062)\end{array}$ \\
\hline Net wealth change since prev elect (lag) & & & $\begin{array}{c}-14.244^{* *} \\
(6.627)\end{array}$ & $\begin{array}{c}-16.392^{* *} \\
(7.661)\end{array}$ & & \\
\hline Financial liabilities change since prev elect (lag) & & & & & $\begin{array}{c}-2.817^{* * *} \\
(0.333)\end{array}$ & $\begin{array}{c}-2.400^{* * *} \\
(0.350)\end{array}$ \\
\hline Constant & $\begin{array}{l}-378.214 \\
(232.177)\end{array}$ & $\begin{array}{l}-230.662 \\
(235.588)\end{array}$ & $\begin{array}{c}-674.832^{* *} \\
(316.491)\end{array}$ & $\begin{array}{l}-731.642^{*} \\
(357.546)\end{array}$ & $\begin{array}{l}-133.312 \\
(184.818)\end{array}$ & $\begin{array}{l}-108.744 \\
(173.470)\end{array}$ \\
\hline Observations & 40 & 40 & 40 & 40 & 40 & 40 \\
\hline R-squared & 0.810 & 0.843 & 0.686 & 0.693 & 0.907 & 0.934 \\
\hline Number of regions & 20 & 20 & 20 & 20 & 20 & 20 \\
\hline
\end{tabular}




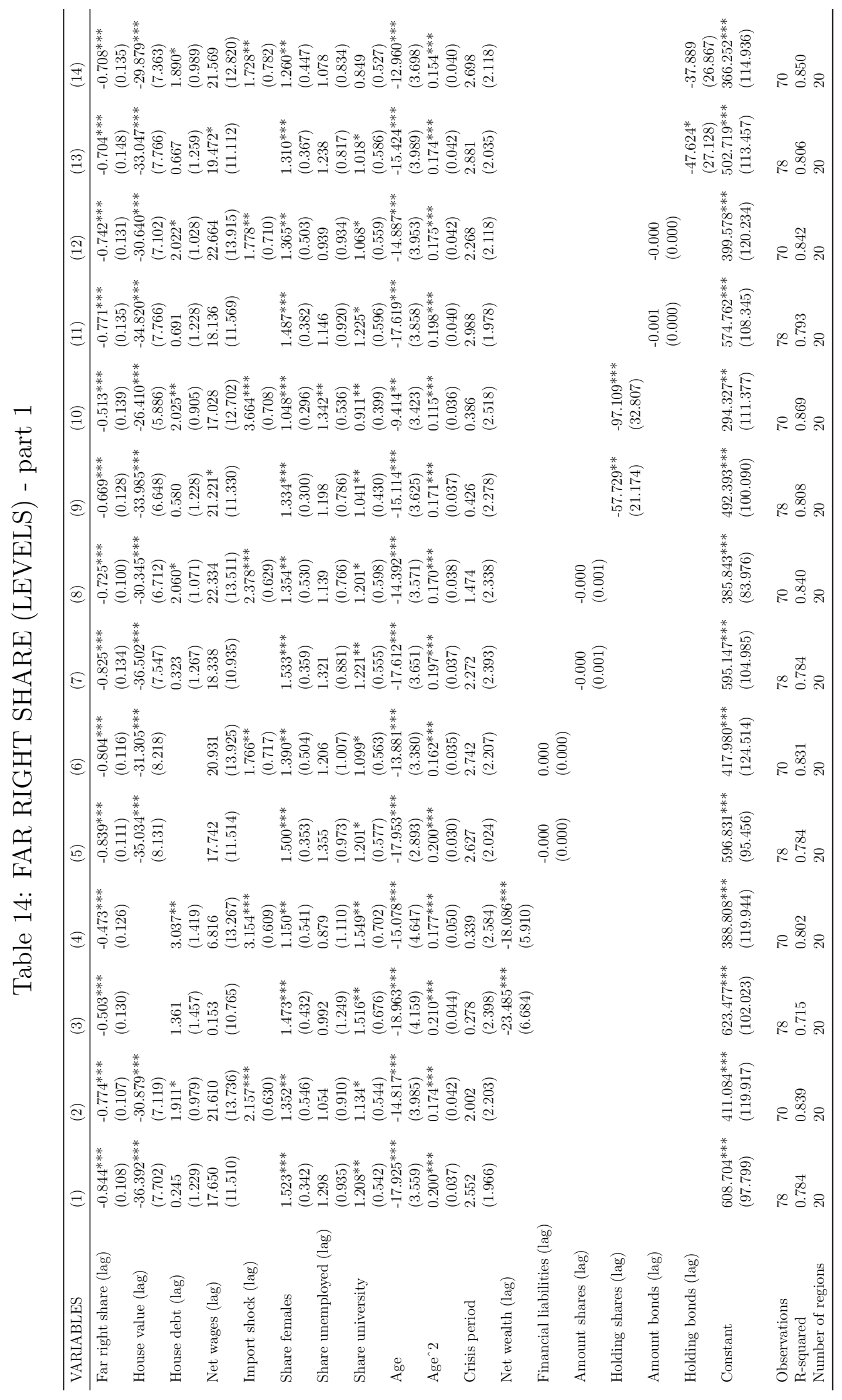




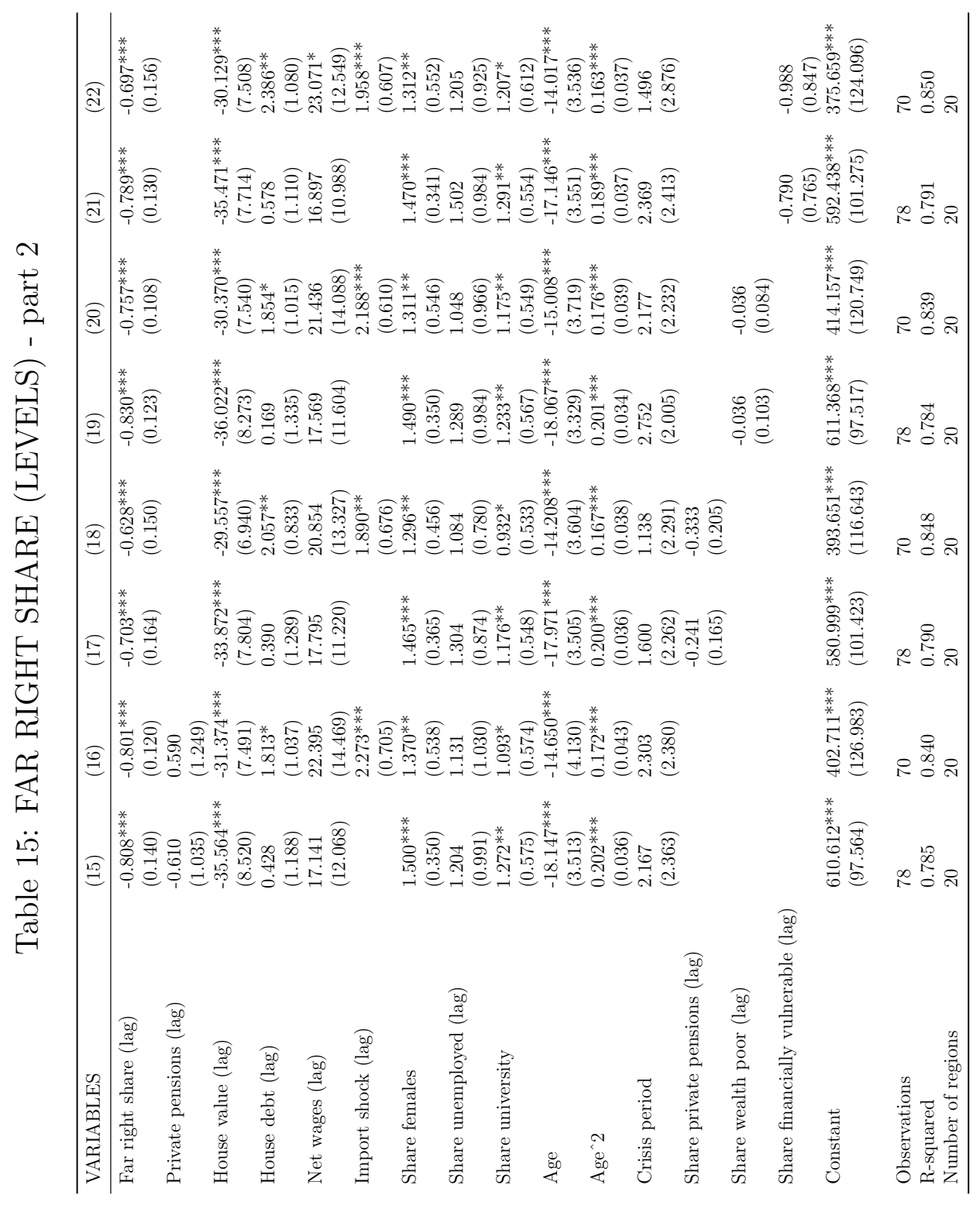




\section{Table 16: FAR RIGHT SHARE, CHANGES SINCE MAX}

\begin{tabular}{|c|c|c|c|c|c|c|}
\hline VARIABLES & (1) & $(2)$ & $(3)$ & $(4)$ & $(5)$ & $(6)$ \\
\hline Far right share (lag) & $\begin{array}{c}-0.445^{* * *} \\
(0.140)\end{array}$ & $\begin{array}{c}-0.520^{* * *} \\
(0.076)\end{array}$ & $\begin{array}{c}-0.369^{* *} \\
(0.154)\end{array}$ & $\begin{array}{c}-0.434^{* * *} \\
(0.096)\end{array}$ & $\begin{array}{c}-0.427^{* * *} \\
(0.141)\end{array}$ & $\begin{array}{c}-0.518^{* * *} \\
(0.074)\end{array}$ \\
\hline House value change since $\max$ (lag) & $\begin{array}{c}-27.916^{* * *} \\
(6.258)\end{array}$ & $\begin{array}{c}-28.268^{* * *} \\
(6.745)\end{array}$ & & & $\begin{array}{c}-23.564^{* * *} \\
(7.978)\end{array}$ & $\begin{array}{c}-25.085^{* * *} \\
(7.591)\end{array}$ \\
\hline House debt change since $\max$ (lag) & $\begin{array}{l}-1.026 \\
(1.211)\end{array}$ & $\begin{array}{c}0.702 \\
(1.065)\end{array}$ & $\begin{array}{c}0.390 \\
(1.285)\end{array}$ & $\begin{array}{l}2.389^{*} \\
(1.345)\end{array}$ & & \\
\hline Net wages change since $\max$ (lag) & $\begin{array}{c}-6.603 \\
(14.874)\end{array}$ & $\begin{array}{c}-3.526 \\
(12.784)\end{array}$ & $\begin{array}{l}-14.997 \\
(14.261)\end{array}$ & $\begin{array}{l}-11.039 \\
(14.889)\end{array}$ & $\begin{array}{c}-6.420 \\
(14.837)\end{array}$ & $\begin{array}{c}-5.178 \\
(12.268)\end{array}$ \\
\hline Import shock (lag) & & $\begin{array}{c}4.102^{* * *} \\
(0.573)\end{array}$ & & $\begin{array}{c}4.200^{* * *} \\
(0.498)\end{array}$ & & $\begin{array}{c}4.044^{* * *} \\
(0.586)\end{array}$ \\
\hline Share females & $\begin{array}{c}0.940 \\
(0.581)\end{array}$ & $\begin{array}{l}0.789^{*} \\
(0.449)\end{array}$ & $\begin{array}{c}0.904 \\
(0.544)\end{array}$ & $\begin{array}{c}0.747 \\
(0.519)\end{array}$ & $\begin{array}{c}1.020 \\
(0.628)\end{array}$ & $\begin{array}{l}0.747^{*} \\
(0.411)\end{array}$ \\
\hline Share unemployed (lag) & $\begin{array}{l}1.612^{* *} \\
(0.763)\end{array}$ & $\begin{array}{l}1.355^{* *} \\
(0.631)\end{array}$ & $\begin{array}{l}1.635 \\
(1.061)\end{array}$ & $\begin{array}{l}1.266 \\
(0.921)\end{array}$ & $\begin{array}{l}1.769^{*} \\
(0.894)\end{array}$ & $\begin{array}{l}1.554^{* *} \\
(0.688)\end{array}$ \\
\hline Share university & $\begin{array}{l}-0.078 \\
(0.487)\end{array}$ & $\begin{array}{l}0.970^{*} \\
(0.528)\end{array}$ & $\begin{array}{c}0.358 \\
(0.570)\end{array}$ & $\begin{array}{l}1.571^{* *} \\
(0.723)\end{array}$ & $\begin{array}{c}0.016 \\
(0.524)\end{array}$ & $\begin{array}{l}0.912^{*} \\
(0.476)\end{array}$ \\
\hline Age & $\begin{array}{c}-19.083^{* * *} \\
(4.716)\end{array}$ & $\begin{array}{c}-10.977^{* * *} \\
(3.311)\end{array}$ & $\begin{array}{c}-19.710^{* * *} \\
(5.013)\end{array}$ & $\begin{array}{c}-11.003^{* *} \\
(4.622)\end{array}$ & $\begin{array}{c}-20.585^{* * *} \\
(4.379)\end{array}$ & $\begin{array}{c}-11.305^{* * *} \\
(3.064)\end{array}$ \\
\hline $\mathrm{Age}^{\wedge} 2$ & $\begin{array}{c}0.205^{* * *} \\
(0.049)\end{array}$ & $\begin{array}{c}0.126^{* * *} \\
(0.036)\end{array}$ & $\begin{array}{c}0.214^{* * *} \\
(0.053)\end{array}$ & $\begin{array}{c}0.129 * * \\
(0.051)\end{array}$ & $\begin{array}{c}0.221^{* * *} \\
(0.044)\end{array}$ & $\begin{array}{c}0.128^{* * *} \\
(0.033)\end{array}$ \\
\hline Crisis period & $\begin{array}{l}-2.109 \\
(1.559)\end{array}$ & $\begin{array}{l}-1.051 \\
(2.307)\end{array}$ & $\begin{array}{l}-2.373 \\
(2.106)\end{array}$ & $\begin{array}{l}-1.665 \\
(2.902)\end{array}$ & $\begin{array}{l}-2.425^{*} \\
(1.392)\end{array}$ & $\begin{array}{l}-0.803 \\
(2.176)\end{array}$ \\
\hline Net wealth change since $\max$ (lag) & & & $\begin{array}{c}-13.525^{*} \\
(6.924)\end{array}$ & $\begin{array}{c}-15.125^{* *} \\
(5.661)\end{array}$ & & \\
\hline Financial liabilities change since max (lag) & & & & & $\begin{array}{l}-4.108 \\
(2.946)\end{array}$ & $\begin{array}{l}-2.574 \\
(2.660)\end{array}$ \\
\hline Constant & $\begin{array}{c}401.041^{* * *} \\
(103.977)\end{array}$ & $\begin{array}{c}191.024^{* *} \\
(67.503)\end{array}$ & $\begin{array}{c}409.052^{* * *} \\
(107.598)\end{array}$ & $\begin{array}{c}183.376^{*} \\
(89.143)\end{array}$ & $\begin{array}{c}431.067^{* * *} \\
(95.802)\end{array}$ & $\begin{array}{c}204.683^{* * *} \\
(66.105)\end{array}$ \\
\hline Observations & 78 & 70 & 78 & 70 & 78 & 70 \\
\hline R-squared & 0.648 & 0.817 & 0.619 & 0.796 & 0.655 & 0.819 \\
\hline Number of regions & 20 & 20 & 20 & 20 & 20 & 20 \\
\hline
\end{tabular}




\section{Table 17: FAR RIGHT SHARE, CHANGES SINCE PREVIOUS ELECTIONS}

\begin{tabular}{|c|c|c|c|c|c|c|}
\hline VARIABLES & $(1)$ & $(2)$ & $(3)$ & $(4)$ & $(5)$ & $(6)$ \\
\hline Share far right (lag) & $\begin{array}{c}-0.500^{* * *} \\
(0.117)\end{array}$ & $\begin{array}{c}-0.513^{* * *} \\
(0.087)\end{array}$ & $\begin{array}{c}-0.348^{* *} \\
(0.144)\end{array}$ & $\begin{array}{c}-0.415^{* * *} \\
(0.089)\end{array}$ & $\begin{array}{c}-0.499 * * * \\
(0.120)\end{array}$ & $\begin{array}{c}-0.511^{* * *} \\
(0.082)\end{array}$ \\
\hline House value change since prev elect (lag) & $\begin{array}{c}-18.915^{* * *} \\
(6.014)\end{array}$ & $\begin{array}{c}-12.041^{*} \\
(6.227)\end{array}$ & & & $\begin{array}{c}-19.615^{* * *} \\
(5.067)\end{array}$ & $\begin{array}{c}-11.708^{*} \\
(5.795)\end{array}$ \\
\hline House debt change since prev elect (lag) & $\begin{array}{l}-0.632 \\
(1.589)\end{array}$ & $\begin{array}{l}-0.094 \\
(1.688)\end{array}$ & $\begin{array}{l}-0.895 \\
(1.681)\end{array}$ & $\begin{array}{l}-0.393 \\
(1.909)\end{array}$ & & \\
\hline Net wages change since prev elect (lag) & $\begin{array}{l}12.206 \\
(8.968)\end{array}$ & $\begin{array}{l}14.239 \\
(9.424)\end{array}$ & $\begin{array}{c}6.107 \\
(8.447)\end{array}$ & $\begin{array}{l}10.584 \\
(8.699)\end{array}$ & $\begin{array}{l}13.166 \\
(8.853)\end{array}$ & $\begin{array}{c}14.137 \\
(10.743)\end{array}$ \\
\hline Import shock (lag) & & $\begin{array}{c}2.917^{* * *} \\
(0.740)\end{array}$ & & $\begin{array}{c}2.955^{* * *} \\
(0.758)\end{array}$ & & $\begin{array}{c}2.946^{* * *} \\
(0.730)\end{array}$ \\
\hline Share females & $\begin{array}{c}0.426 \\
(0.694)\end{array}$ & $\begin{array}{c}0.395 \\
(0.432)\end{array}$ & $\begin{array}{c}0.379 \\
(0.687)\end{array}$ & $\begin{array}{c}0.365 \\
(0.474)\end{array}$ & $\begin{array}{c}0.445 \\
(0.703)\end{array}$ & $\begin{array}{c}0.381 \\
(0.417)\end{array}$ \\
\hline Share unemployed (lag) & $\begin{array}{c}1.457 \\
(1.008)\end{array}$ & $\begin{array}{l}1.065 \\
(0.936)\end{array}$ & $\begin{array}{c}1.844 \\
(1.112)\end{array}$ & $\begin{array}{l}1.348 \\
(0.904)\end{array}$ & $\begin{array}{l}1.395 \\
(0.992)\end{array}$ & $\begin{array}{l}1.154 \\
(1.108)\end{array}$ \\
\hline Share university & $\begin{array}{c}0.174 \\
(0.497)\end{array}$ & $\begin{array}{c}0.974 \\
(0.660)\end{array}$ & $\begin{array}{c}0.240 \\
(0.532)\end{array}$ & $\begin{array}{l}1.040 \\
(0.659)\end{array}$ & $\begin{array}{c}0.223 \\
(0.513)\end{array}$ & $\begin{array}{c}0.979 \\
(0.652)\end{array}$ \\
\hline Age & $\begin{array}{c}-21.064^{* * *} \\
(4.074)\end{array}$ & $\begin{array}{c}-13.186^{* * *} \\
(3.634)\end{array}$ & $\begin{array}{c}-20.547^{* * *} \\
(4.939)\end{array}$ & $\begin{array}{c}-12.744^{* * *} \\
(3.914)\end{array}$ & $\begin{array}{c}-21.435^{* * *} \\
(3.979)\end{array}$ & $\begin{array}{c}-12.998^{* * *} \\
(4.250)\end{array}$ \\
\hline Age^2 & $\begin{array}{c}0.235^{* * *} \\
(0.044)\end{array}$ & $\begin{array}{c}0.158^{* * *} \\
(0.039)\end{array}$ & $\begin{array}{c}0.227^{* * *} \\
(0.053)\end{array}$ & $\begin{array}{c}0.151^{* * *} \\
(0.042)\end{array}$ & $\begin{array}{c}0.239^{* * *} \\
(0.043)\end{array}$ & $\begin{array}{c}0.155^{* * *} \\
(0.047)\end{array}$ \\
\hline Crisis period & $\begin{array}{l}-4.195^{*} \\
(2.035)\end{array}$ & $\begin{array}{l}-0.866 \\
(2.649)\end{array}$ & $\begin{array}{l}-2.078 \\
(2.215)\end{array}$ & $\begin{array}{c}0.739 \\
(2.509)\end{array}$ & $\begin{array}{c}-4.255^{* *} \\
(1.956)\end{array}$ & $\begin{array}{l}-0.791 \\
(2.553)\end{array}$ \\
\hline Net wealth change since prev elect & & & $\begin{array}{c}-11.272^{* *} \\
(5.094)\end{array}$ & $\begin{array}{l}-6.295 \\
(3.656)\end{array}$ & & \\
\hline Financial liabilities change since prev elect & & & & & $\begin{array}{l}-0.485 \\
(0.695)\end{array}$ & $\begin{array}{l}-0.368 \\
(0.583)\end{array}$ \\
\hline Constant & $\begin{array}{c}456.479^{* * *} \\
(96.464)\end{array}$ & $\begin{array}{c}248.083^{* * *} \\
(76.200)\end{array}$ & $\begin{array}{c}447.534^{* * *} \\
(111.982)\end{array}$ & $\begin{array}{c}239.350^{* * *} \\
(81.083)\end{array}$ & $\begin{array}{c}463.891^{* * *} \\
(93.344)\end{array}$ & $\begin{array}{c}244.871^{* *} \\
(87.966)\end{array}$ \\
\hline Observations & 78 & 70 & 78 & 70 & 78 & 70 \\
\hline R-squared & 0.638 & 0.779 & 0.622 & 0.770 & 0.638 & 0.780 \\
\hline Number of regions & 20 & 20 & 20 & 20 & 20 & 20 \\
\hline
\end{tabular}




\section{References}

Adler, David and Ben W. Ansell (June 2019). "Housing and populism". In: West European Politics, pp. 1-22. ISSN: 0140-2382. DOI: 10.1080/01402382.2019.1615322. URL: https://doi.org/10.1080/01402382.2019.1615322.

Ahlquist, John, Mark Copelovitch, and Stefanie Walter (2020). "The Political Consequences of External Economic Shocks: Evidence from Poland". en. In: American Journal of Political Science n/a.n/a. ISSN: 1540-5907. DOI: 10.1111/ajps . 12503. URL: http : / / onlinelibrary . wiley . com/doi / abs / 10.1111 /ajps . 12503 (visited on $07 / 24 / 2020)$.

Algan, Yann et al. (2017). "The European Trust Crisis and the Rise of Populism". In: Brookings Papers on Economic Activity 2, pp. 309-382. ISSN: 0007-2303. URL: https://www.jstor.org/stable/90019460 (visited on 09/19/2019).

Ansell, Ben W. (May 2014). "The Political Economy of Ownership: Housing Markets and the Welfare State". In: American Political Science Review 108.2, pp. 383-402. ISSN: 0003-0554, 1537-5943. DOI: 10.1017/S0003055414000045. URL: https : / /ww . cambridge .org/core/journals/american-political-science-review/article/the-politicaleconomy-of-ownership-housing-markets-and-the-welfare-state/F9F0C1F7146D3F35CA3856CD981E5567 (visited on $04 / 22 / 2017)$.

Ansell, Ben W. and David Adler (2019). "Brexit and the Politics of Housing in Britain". en. In: The Political Quarterly 90.S2, pp. 105-116. ISSN: 1467-923X. DOI: 10.1111/1467-923X.12621. URL: https://onlinelibrary.wiley.com/ doi/abs/10.1111/1467-923X.12621 (visited on 05/17/2019).

Ansell, Ben W. and Asli Cansunar (Mar. 2020). Local Economies, Local Wealth, and Economic Perceptions.

Autor, David H., David Dorn, Gordon Hanson, et al. (Sept. 2016). Importing Political Polarization? The Electoral Consequences of Rising Trade Exposure. Working Paper 22637. National Bureau of Economic Research. DOI: 10 . 3386/w22637. URL: http://www.nber.org/papers/w22637 (visited on 06/25/2019).

Autor, David H., David Dorn, and Gordon H. Hanson (2016). "The China Shock: Learning from Labor-Market Adjustment to Large Changes in Trade". In: Annual Review of Economics 8.1, pp. 205-240. DOI: 10.1146/annureveconomics-080315-015041. URL: https : //doi .org/10.1146/annurev-economics-080315-015041 (visited on $06 / 25 / 2019$ ).

Banca d'Italia, Report (Mar. 2018). Survey on Household Income and Wealth - 2016. en. Tech. rep. Library Catalog: www.bancaditalia.it. URL: https : //www bancaditalia.it/pubblicazioni/indagine-famiglie/bil-fam2016/ index.html (visited on 08/05/2020).

Bank for International Settlements, Report (June 2019). Annual Economic Report 2019. en. Tech. rep. Basel: BIS. URL: https://www.bis.org/publ/arpdf/ar2019e.pdf (visited on 03/30/2020).

Berman, Sheri (2006). The Primacy of Politics: Social Democracy and the Making of Europe's Twentieth Century. New York, NY: Cambridge University Press. ISBN: 0-521-81799-4.

Berman, Sheri and Maria Snegovaya (July 2019). "Populism and the Decline of Social Democracy". en. In: Journal of Democracy 30.3, pp. 5-19. ISSN: 1086-3214. DOI: 10.1353/jod.2019.0038. URL: https://muse.jhu.edu/article/ 729165 (visited on 08/08/2019).

Bloise, Francesco, Daniela Chironi, and Mario Pianta (2019). "Inequality and elections in Italian regions". In:

Burgoon, Brian et al. (Jan. 2019). "Positional deprivation and support for radical right and radical left parties". en. In: Economic Policy 34.97, pp. 49-93. ISSN: 0266-4658. DOI: 10.1093/epolic/eiy017. URL: https://academic.oup. com/economicpolicy/article/34/97/49/5258471 (visited on 06/19/2019).

Carreras, Miguel, Yasemin Irepoglu Carreras, and Shaun Bowler (Mar. 2019). "Long-Term Economic Distress, Cultural Backlash, and Support for Brexit". en. In: Comparative Political Studies, p. 0010414019830714. ISSN: 0010-4140. DOI: 10.1177/0010414019830714. URL: https://doi.org/10.1177/0010414019830714 (visited on 06/10/2019).

Cerrato, Andrea, Federico Maria Ferrara, and Francesco Ruggieri (2018). Why Does Import Competition Favor Republicans? Localized Trade Shocks, Voting Behavior, and Scapegoating in the U.S.

Chwieroth, Jeffrey and Andrew Walter (Apr. 2019). "The financialization of mass wealth, banking crises and politics over the long run". In: European Journal of International Relations 25.4, pp. 1007-1034. ISSN: 1354-0661. DOI: 10.1177/1354066119843319. URL: https://doi.org/10.1177/1354066119843319 (visited on 04/21/2019).

- (June 2020). "Financialization, wealth and the changing political aftermaths of banking crises". en. In: SocioEconomic Review. DOI: 10.1093/ser/mwaa017. URL: https://academic.oup.com/ser/advance-article/doi/10. 1093/ser/mwaa017/5854856 (visited on 06/16/2020).

Colantone, Italo and Piero Stanig (May 2018a). "Global Competition and Brexit". en. In: American Political Science Review 112.2, pp. 201-218. ISSN: 0003-0554, 1537-5943. DOI: 10.1017/S0003055417000685. URL: https: //www . cambridge . org / core / journals / american- political - science - review / article / global - competition - and brexit/C843990101DB9232B654E77130F88398 (visited on 06/25/2019).

- (2018b). "The Trade Origins of Economic Nationalism: Import Competition and Voting Behavior in Western Europe". en. In: American Journal of Political Science 62.4, pp. 936-953. ISSN: 1540-5907. DOI: 10.1111/ajps . 12358. URL: https://onlinelibrary.wiley.com/doi/abs/10.1111/ajps.12358 (visited on 08/14/2019).

Collier, Paul (2018). The Future of Capitalism: Facing the New Anxieties. en. London: Allen Lane. URL: /books/307625/ the-future-of-capitalism/9780141987255 (visited on 06/13/2019).

D'Alimonte, Roberto (2019). "How the populists won in Italy". In: Journal of Democracy 30.1, pp. 114-127.

Dal Bo, Ernesto et al. (Feb. 2019). Economic Losers and Political Winners: Sweden's Radical Right. 
Doerr, Sebastian et al. (May 2019). From Finance to Fascism: The Real Effect of Germany's 1931 Banking Crisis. en. Tech. rep. 1092. Publication Title: Working Papers. Barcelona Graduate School of Economics. URL: https: //ideas.repec.org/p/bge/wpaper/1092.html (visited on 07/15/2020).

Eichengreen, Barry J. (May 2018). The Populist Temptation: Economic Grievance and Political Reaction in the Modern Era. en. Google-Books-ID: BVZYDwAAQBAJ. Oxford University Press. ISBN: 978-0-19-086629-7.

Enos, Ryan D. (2017). The Space between Us: Social Geography and Politics. Cambridge: Cambridge University Press. ISBN: 978-1-108-42064-8. DOI: 10 .1017/9781108354943. URL: https ://www . cambridge .org/core/books/spacebetween-us/EA1109A01102D4EF2C71A3125AD07B41.

Evans, Geoffrey and James Tilley (Feb. 2017). The New Politics of Class: The Political Exclusion of the British Working Class. en. Oxford: Oxford University Press. ISBN: 978-0-19-181690-1. uRL: https://www .oxfordscholarship.com/ view/10.1093/acprof : oso/9780198755753.001.0001/acprof-9780198755753 (visited on 06/24/2019).

Fetzer, Thiemo (June 2019). Did Austerity Cause Brexit? URL: https://warwick.ac.uk/fac/soc/economics/research/ centres/cage/manage/publications/381-2018_fetzer.pdf.

Ford, Robert and Matthew J. Goodwin (Mar. 2014). Revolt on the Right: Explaining Support for the Radical Right in Britain. en. Google-Books-ID: c5oXAwAAQBAJ. Routledge. ISBN: 978-1-317-93854-5.

Frank, Robert H. (2013). Falling Behind: How Rising Inequality Harms the Middle Class. The Aaron Wildavsky forum for public policy: 4. Berkeley, CA: University of California Press.

Funke, Manuel, Moritz Schularick, and Christoph Trebesch (2016). "Going to Extremes: Politics After Financial Crises, 1870-2014". In: European Economic Review 88.C, pp. 227-260. ISSN: 0014-2921. URL: brom (visited on 01/04/2017).

Garcia-Macia, Daniela (Aug. 2018). Household Wealth and Resilience to Financial Shocks in Italy. en. Tech. rep. Washington, D.C.: IMF. URL: http://www.imf .org/en/Publications/WP/Issues/2018/08/31/Household-Wealthand-Resilience-to-Financial-Shocks-in-Italy-46168 (visited on 08/06/2020).

Gennaioli, Nicola and Guido Tabellini (June 2019). Identity, Beliefs, and Political Conflict. Tech. rep. DP13390. London: CEPR. URL: https://cepr.org/active/publications/discussion_papers/dp.php?dpno=13390.

Gidron, Noam and Peter A. Hall (2017). "The politics of social status: economic and cultural roots of the populist right". en. In: The British Journal of Sociology 68.S1, S57-S84. ISSN: 1468-4446. DOI: 10.1111/1468-4446.12319. URL: https://onlinelibrary.wiley.com/doi/abs/10.1111/1468-4446.12319 (visited on 06/24/2019).

Guiso, Luigi et al. (Feb. 2017). Demand and Supply of Populism. en. Tech. rep. 1703. Einaudi Institute for Economics and Finance (EIEF). URL: https://ideas.repec.org/p/eie/wpaper/1703.html (visited on 06/25/2019).

Gyongyosi, Gyozo and Emil Verner (Apr. 2019). Financial Crisis, Creditor-Debtor Conflict, and Populism. en. SSRN Scholarly Paper ID 3289741. Rochester, NY: Social Science Research Network. DOI: 10.2139/ssrn. 3289741. URL: https://papers.ssrn.com/abstract=3289741 (visited on 08/05/2020).

Hopkin, Jonathan (June 2020). Anti-System Politics: The Crisis of Market Liberalism in Rich Democracies. Oxford, New York: Oxford University Press. ISBN: 978-0-19-069976-5.

Inglehart, Ronald (1997). Modernization and Postmodernization: Cultural, Economic, and Political Change in 43 Societies. en. Princeton, N.J.: Princeton University Press. URL: https ://press.princeton.edu/titles/5981.html (visited on 06/25/2019).

Inglehart, Ronald and Pippa Norris (July 2016). Trump, Brexit, and the Rise of Populism: Economic Have-Nots and Cultural Backlash. SSRN Scholarly Paper ID 2818659. Rochester, NY: Social Science Research Network. URL: https: //papers.ssrn. com/abstract=2818659 (visited on 02/04/2017).

Kriesi, Hanspeter (2014). "The Political Consequences of the Economic Crisis in Europe: Electoral Punishment and Popular Protest". eng. In: Mass Politics in Tough Times: Opinions, Votes, and Protest in the Great Recession. Ed. by Nancy Gina Bermeo and Larry M. Bartels. New York, NY: Oxford University Press, pp. 297-333. ISBN: 978-0-19-935750-5.

Laeven, Luc and Fabián Valencia (Sept. 2018). Systemic Banking Crises Revisited. Tech. rep. Washington, D.C.: IMF. URL: https : //www.imf .org/en/Publications/WP/Issues/2018/09/14/Systemic-Banking-Crises-Revisited46232 .

Lewis-Beck, Michael S., Richard Nadeau, and Martial Foucault (Apr. 2013). "The Compleat Economic Voter: New Theory and British Evidence". en. In: British Journal of Political Science 43.2, pp. 241-261. ISSN: 0007-1234, 1469-2112. DOI: 10 . 1017 / S0007123412000440. URL: https : / / www . cambridge . org / core / journals / britishjournal-of-political-science/article/the-compleat-economic-voter-new-theory-and-british-evidence/ 641FBAB0F5CD21788D4F1C73EAC97647 (visited on 07/18/2018).

Massey, Andrew, ed. (2013). Public Sector Reform. en. Thousand Oaks, CA: Sage. URL: https://au.sagepub.com/engb/oce/public-sector-reform/book237788 (visited on 08/07/2019).

Merler, Silvia (July 2016). Italy's bail-in headache. en-US. URL: http://bruegel .org/2016/07/italys-bail-inheadache/ (visited on 04/20/2018).

- (June 2017). A Tangled Tale of Bank Liquidation in Venice. en-US. URL: http ://bruegel . org/2017/06/atangled-tale-of-bank-liquidation-in-venice/ (visited on 04/12/2018).

Milner, Helen V. (Sept. 2018). Globalization and its Political Consequences: The Effects on Party Politics in the West.

- (Feb. 2019). Globalisation, populism and the decline of the welfare state. en. URL: https://www.iiss.org/blogs/ survival-blog / 2019/02/globalisation-populism-and-the-decline-of - the-welfare-state (visited on 06/13/2019).

Morgan, Stephen L. (Jan. 2018). "Correct Interpretations of Fixed-effects Models, Specification Decisions, and Selfreports of Intended Votes: A Response to Mutz". en. In: Socius 4, p. 2378023118811502. ISSN: 2378-0231. DOI: 10.1177/2378023118811502. URL: https://doi.org/10.1177/2378023118811502 (visited on 06/21/2019). 
Mudde, Cas and Rovira Kaltwasser Cristobal (Feb. 2017). Populism: A Very Short Introduction. English. 2nd ed. edition. New York, NY: Oxford University Press. ISBN: 978-0-19-023487-4.

Mudge, Stephanie L. (2018). Leftism Reinvented: Western Parties from Socialism to Neoliberalism. en. Cambridge, MA: Harvard University Press. URL: https : //www .hup.harvard.edu/catalog.php? isbn=9780674971813 (visited on $08 / 09 / 2019)$.

Müller, Jan-Werner (May 2019). "Populism and the People". In: London Review of Books 41.10, pp. 35-37. ISSN: 02609592. URL: https : //www. lrb.co.uk/v41/n10/jan-werner-muller/populism-and-the-people (visited on 07/09/2019).

Mutz, Diana C. (Jan. 2018). "Response to Morgan: On the Role of Status Threat and Material Interests in the 2016 Election". en. In: Socius 4, p. 2378023118808619. ISSN: 2378-0231. DOI: 10.1177/2378023118808619. URL: https: //doi.org/10.1177/2378023118808619 (visited on 06/14/2019).

Norris, Pippa and Ronald Inglehart (Feb. 2019). Cultural Backlash by Pippa Norris. en. DOI: 10.1017/9781108595841. URL: /core/books/cultural-backlash/3C7CB32722C7BB8B19A0FC005CAFD02B (visited on 06/10/2019).

OECD (2019). Under Pressure: The Squeezed Middle Class. en. (Visited on 05/17/2019).

Persson, Mikael and Johan Martinsson (2018). "Patrimonial Economic Voting and Asset Value - New Evidence from Taxation". In: British Journal of Political Science 48.3, pp. 825-842. URL: https://www . cambridge.org/core/ journals/british-journal-of-political-science/article/div-classtitlepatrimonial-economic-votingand-asset-value-new-evidence-from-taxation-register-datadiv/5C08CD3BAA70AF312109F1D3DD064443 (visited on $07 / 18 / 2018)$.

Piketty, Thomas (May 2019). Brahmin Left vs Merchant Right: Rising Inequality and the Changing Structure of Political Conflict (Evidence from France, Britain and the US, 1948-2017).

Rodríguez-Pose, Andrés (Mar. 2018). "The revenge of the places that don't matter (and what to do about it)". en. In: Cambridge Journal of Regions, Economy and Society 11.1, pp. 189-209. ISSN: 1752-1378. DOI: 10.1093/cjres/ rsx024. URL: https://academic.oup.com/cjres/article/11/1/189/4821289 (visited on 06/10/2019).

Rodrik, Dani (June 2018). "Populism and the economics of globalization". en. In: Journal of International Business Policy 1.1, pp. 12-33. ISSN: 2522-0705. DOI: 10.1057/s42214-018-0001-4. URL: https://doi.org/10.1057/s42214018-0001-4 (visited on 06/25/2019).

- (July 2020). Why Does Globalization Fuel Populism? Economics, Culture, and the Rise of Right-wing Populism. en. Tech. rep. 27526. Publication Title: NBER Working Papers. National Bureau of Economic Research, Inc. URL: https://ideas.repec.org/p/nbr/nberwo/27526.html (visited on 08/06/2020).

Rooduijn, M. et al. (2019). The PopuList: An Overview of Populist, Far Right, Far Left and Eurosceptic Parties in Europe. en-GB. Library Catalog: popu-list.org. URL: https://popu-list.org/ (visited on 08/05/2020).

Rooduijn, Matthijs and Tjitske Akkerman (2017). "Flank attacks: Populism and left-right radicalism in Western Europe". In: Party Politics 23.3, pp. 193-204.

Steiner, Nils D. and Philipp Harms (May 2020). Local Trade Shocks and the Nationalist Backlash in Political Attitudes: Panel Data Evidence from Great Britain. en. Tech. rep. 2014. Publication Title: Working Papers. Gutenberg School of Management and Economics, Johannes Gutenberg-Universität Mainz. URL: https://ideas.repec.org/p/jgu/ wpaper/2014.html (visited on 08/06/2020).

Taguieff, Pierre-André (2003). L'illusione populista. Vol. 40. Pearson Italia Spa.

Vlandas, Tim and Daphne Halikiopoulou (May 2018). "Does unemployment matter? Economic insecurity, labour market policies and the far-right vote in Europe". en. In: European Political Science. ISSN: 1682-0983. DOI: 10.1057/s41304018-0161-z. URL: https://doi.org/10.1057/s41304-018-0161-z (visited on 06/25/2019).

Wilkinson, Will (June 2019). The Density Divide: Urbanization, Polarization, and Populist Backlash. en-US. Tech. rep. URL: https : //niskanencenter . org/blog/the-density-divide-urbanization-polarization-and-populistbacklash/ (visited on 07/10/2019). 